\title{
Distribution of surface carbon dioxide and air-sea exchange in the upwelling system off the Galician coast
}

\author{
Alberto V. Borges and Michel Frankignoulle \\ Unité d'Océanographie Chimique, Institut de Physique B5, Université de Liège, Sart Tilman, Belgium
}

Received 28 December 2000; revised 11 July 2001; accepted 23 July 2001; published 21 May 2002.

[1] Data on the distribution of the partial pressure of $\mathrm{CO}_{2}\left(\mathrm{CCO}_{2}\right)$ were obtained during six cruises off the Galician coast, a region characterized by a seasonal upwelling. The values of $p \mathrm{CO}_{2}$ over the continental shelf are highly variable and range between 265 and $415 \mu \mathrm{atm}$ during the upwelling season and between 315 and $345 \mu \mathrm{atm}$ during the downwelling season. Both the continental shelf and off-shelf waters behave as significant net sinks of atmospheric $\mathrm{CO}_{2}$. The computation of the air-sea fluxes of $\mathrm{CO}_{2}$ over the continental shelf yields a net influx in the range of $-2.3( \pm 0.6)$ to $-4.7( \pm 1.0) \mathrm{mmol} \mathrm{C} \mathrm{m}^{-2} \mathrm{~d}^{-1}$ during the upwelling season and $-3.5( \pm 0.8)$ to $-7.0( \pm 1.5) \mathrm{mmol} \mathrm{C}$ $\mathrm{m}^{-2} \mathrm{~d}^{-1}$ on an annual basis. During the upwelling season and on an annual basis, although the observed air-sea gradients of $\mathrm{CO}_{2}$ over the continental shelf are significantly stronger than those in off-shelf waters, the computed air-sea $\mathrm{CO}_{2}$ fluxes are not significantly different because of the important incertitude introduced in the calculations by the estimated error on wind speed measurements. The presence of upwelling filaments increases the influx of atmospheric $\mathrm{CO}_{2}$ in the off-shelf waters. During summer, important short-term variations of $p \mathrm{CO}_{2}$ are observed that are related to both upwelling and temperature variations. During winter the cooling of water causes important undersaturation of $\mathrm{CO}_{2}$ related to the effect of temperature on the dissolved inorganic carbon equilibrium constants. INDEX TERMS: 4219 Oceanography: General: Continental shelf processes; 4243 Oceanography: General: Marginal and semienclosed seas; 4805 Oceanography: Biological and Chemical: Biogeochemical cycles (1615); 4820 Oceanography: Biological and Chemical: Gases; KEYWORDS: coastal upwelling, $\mathrm{CO}_{2}$ air-sea exchange, Galician, ocean margin exchange, continental shelf

\section{Introduction}

[2] Two recent papers by Gattuso et al. [1998] and Wollast [1998] emphasize the complexity of the carbon cycle in the coastal sea and its potential global importance. The first paper reviews available data of gross primary production and ecosystem respiration and suggests that all coastal ecosystems are net autotrophic, except estuaries. The second paper synthesizes available carbon fluxes across the continental shelf break and yields the same conclusion, i.e., that distal continental shelves are net autotrophic. Further evidence comes from recent annual budgets of air-sea fluxes of $\mathrm{CO}_{2}$ derived from high temporal and spatial resolution surface $p \mathrm{CO}_{2}$ data sets in the East China Sea [Tsunogai et al., 1999; Wang et al., 2000] and in the Gulf of Biscay [Frankignoulle and Borges, 2001] that both yield annual integrated $\mathrm{CO}_{2}$ fluxes ranging from -3.3 to $-7.9 \mathrm{mmol} \mathrm{C} \mathrm{m}^{-2} \mathrm{~d}^{-1}$. Moreover, a carbon biogeochemical model calibrated with $p \mathrm{CO}_{2}$ field data yields similar air-sea $\mathrm{CO}_{2}$ flux values in the Baltic Sea [Thomas and Schneider, 1999]. The extrapolation of these fluxes to the continental shelf surface area worldwide yields an influx of atmospheric $\mathrm{CO}_{2}$ of $\sim 1.0 \mathrm{Gt} \mathrm{C} \mathrm{yr}^{-1}$ [Tsunogai et al., 1999]. This so far neglected flux, named the "continental shelf pump" by Tsunogai et al. [1999], is significant when compared to the one reported for the open oceanic waters that range between 0.7 and $2.2 \mathrm{Gt} \mathrm{C}$ year $^{-1}$ [e.g., Takahashi et al., 1997, 1999]. However, further verification of the continental shelf pump hypothesis is needed and relies on additional acquisition of $p \mathrm{CO}_{2}$ data with a high temporal and

Copyright 2002 by the American Geophysical Union. 0886-6236/02/2000GB001385\$12.00 spatial resolution in different coastal environments [Frankignoulle and Borges, 2001]. Indeed, proximal continental shelves that are directly influenced by river inputs are known to be net heterotrophic [Smith and Mackenzie, 1987; Smith and Hollibaugh, 1993; Gattuso et al., 1998] and behave as net emitters of atmospheric $\mathrm{CO}_{2}$ [Frankignoulle et al., 1998; Borges and Frankignoulle, 1999; Cai et al., 1999].

[3] Coastal upwelling areas are known to show important oversaturation of $\mathrm{CO}_{2}$ with respect to the atmosphere due to the input of $\mathrm{CO}_{2}$-rich deep waters. However, the input of nutrients from upwelling fuels important primary production [e.g., Walsh, 1988] that in turn lowers $p \mathrm{CO}_{2}$ values. Each of these two processes has then an antagonistic effect on the gradient of $\mathrm{CO}_{2}$ across the air-sea interface, and so far, it is difficult to access the role of coastal upwelling areas either as sources or sinks of atmospheric $\mathrm{CO}_{2}$. For instance, in the Peruvian and Chilean coastal upwelling systems that are known to be among the most productive oceanic areas worldwide, huge oversaturation of $\mathrm{CO}_{2}$ with respect to the atmosphere has been reported with $\mathrm{pCO}_{2}$ values up to $1200 \mu \mathrm{atm}$, although very low values down to $140 \mu \mathrm{atm}$ have also been observed in relation to inorganic carbon fixation by phytoplankton [Kelley and Hood, 1971; Simpson and Zirino, 1980; CopinMontégut and Raimbault, 1994; Torres et al., 1999]. Other upwelling systems show a lesser range of variation, 130-690 $\mu \mathrm{atm}$ off the California coast [Simpson, 1984; Van Green et al., 2000], 300-450 $\mu \mathrm{atm}$ off the Mauritanian coast [Copin-Montégut and Avril, 1995; Lefèvre et al., 1998; Bakker et al., 1999], and 365-750 $\mu \mathrm{atm}$ off the Omani coast [Körtzinger et al., 1997; Goyet et al., 1998; Sabine et al., 2000]. These studies in most cases cover a small fraction of the annual cycle and do not allow integration of fluxes on an 


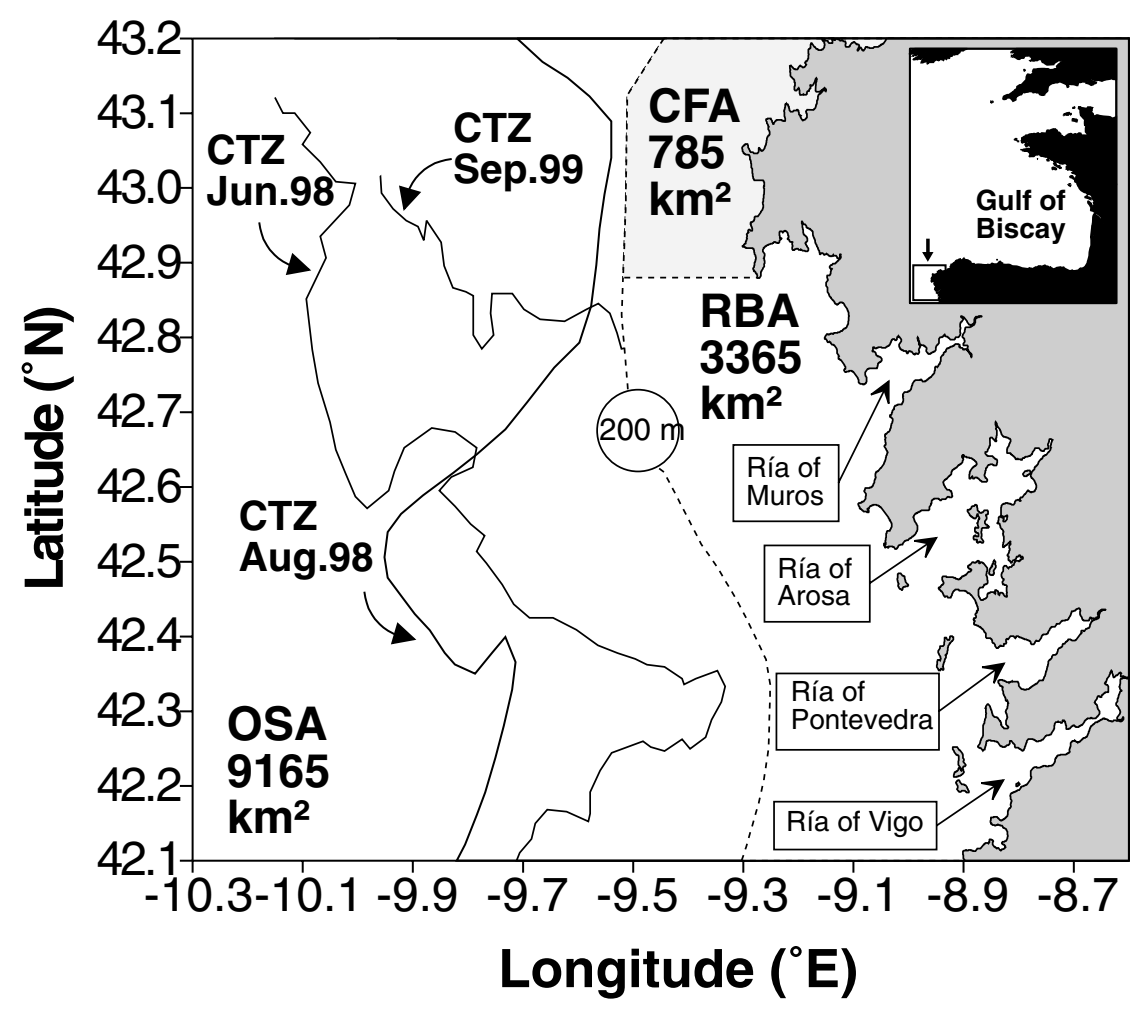

Figure 1. Map of the study region. The dashed line corresponds to the $200 \mathrm{~m}$ isobath (i.e., the shelf break). The limit of $\mathrm{CTZ}$ was determined for each cruise from the $17.5^{\circ} \mathrm{C}$ isotherm that corresponded to the boundary between offshore waters and two upwelling filaments studied in detail from the point of view of dissolved inorganic carbon by Borges and Frankignoulle [2001] using a Lagrangian approach. The $17.5^{\circ} \mathrm{C}$ isotherm was extracted from interpolated maps of temperature (Figures 2 and 3) for the June 1998 and September 1999 cruises and from a sea surface temperature (SST) image of the 18 August 1998. CFA, Cape Finisterre Area; RBA, Rías Baixas Area; OSA, offshore area; CTZ, coastal transition zone.

annual basis. The exception is the study by Goyet et al. [1998], which yields an annually integrated flux of $\mathrm{CO}_{2}$ across the air-sea interface of $+2.5 \mathrm{mmol} \mathrm{C} \mathrm{m} \mathrm{d}^{-1}$.

[4] The Galician coast (northwestern Spain) is the northernmost part of the North Atlantic eastern boundary upwelling system. The oscillation between the upwelling and the downwelling seasons depends on the seasonal displacement of the Açores anticyclone. From April to October, winds along the coast are predominantly equatorward, inducing upwelling on to the continental shelf of nutrient-rich subpolar Eastern North Atlantic Water (ENAW) with a cycle of upwelling and relaxation characterized by a period of 14 ( \pm 4 ) days [McClain et al., 1986; Álvarez-Salgado et al., 1993]. From August to October, upwelling filaments develop in the area, with a maximum frequency of occurrence in mid-September. These structures are tongues of cold upwelled water that extend offshore from the coast with a mean length of $150 \mathrm{~km}$. Off Cape Finisterre the length and occurrence of upwelling filaments is among the most important off the Iberian coast [Haynes et al., 1993]. Another characteristic feature of the Galician coast is the presence of the Rías Baixas (Figure 1). These embayments are flooded tectonic valleys that act during winter as mixed estuaries when the flow of fresh water is high $\left(>30 \mathrm{~m}^{3} \mathrm{~s}^{-1}\right.$ [Nogueira et al., 1997]). During summer, when the flow of fresh water is negligible $\left(<10 \mathrm{~m}^{3} \mathrm{~s}^{-1}\right.$ [Nogueira et al., 1997]), upwelling occurs within the rías that then act as an extension of the continental shelf, as first described by Fraga [1981] and clearly evidenced by numerous studies [e.g., Alvarez-Salgado et al., 1993, 1999; Doval et al., 1997; Nogueira et al., 1997, 1998]. The water circulation in the rías is two-layered, the bottom layer corresponding to upwelled ENAW that enters the ría during an upwelling event and pushes the surface layer water out of the ría. This phenomenon is described in literature as "outwelling" from the rías. The outwelled surface water is modified ENAW that entered the ría during the upwelling event of the previous upwelling cycle. Thus the physicochemical and biological characteristics of this water mass are related to the relaxation stage that preceded the ongoing upwelling event. The outwelled water is warm and has undergone important primary production related to the input of nutrients from upwelled ENAW, sediment remineralization, and to a lesser extent, the input of fresh water [e.g., Álvarez-Salgado et al., 1993]. For instance, in the Ría of Vigo the mean annual value of net primary production is 70 $( \pm 10) \mathrm{mmol} \mathrm{C} \mathrm{m}^{-2} \mathrm{~d}^{-1}$ [Alongi, 1998], ranging during the upwelling season between $5( \pm 1)$ and $310( \pm 60) \mathrm{mmol} \mathrm{C} \mathrm{m} \mathrm{C}^{-2} \mathrm{~d}^{-1}$ [Tilstone et al., 1999] (the incertitude on primary production rates, here and in the rest of the text, was estimated from a consensual value of $\pm 20 \%$ given by the Ocean Margin EXchange (OMEX) II phytobiologists since none of the publications mention error estimates). The mean annual value of net primary production over the adjacent continental shelf is $50( \pm 10) \mathrm{mmol} \mathrm{C} \mathrm{m} \mathrm{m}^{-2} \mathrm{~d}^{-1}$ according to Álvarez-Salgado et al. [2001].

[5] From October to March, when coastal winds are predominantly northward, a poleward slope current develops from Cape São Vincente $\left(37^{\circ} \mathrm{N}\right)$ along the Iberian coast into the Armorican shelf [Frouin et al., 1990; Haynes and Barton, 1990, 1991; Pingree 
Table 1. Cruises Carried out in the Galician Upwelling System During the Ocean Margin EXchange (OMEX) II Project

\begin{tabular}{lcl}
\hline \multicolumn{1}{c}{ Ship } & Cruise Number & \multicolumn{1}{c}{ Cruise Duration } \\
\hline RV Belgica (Belgium) & BG 97/14 & 18 June 1997 to 7 July 1997 \\
RRS Charles Darwin (United Kingdom) & CD 110B & 6 Jan. 1998 to 19 Jan. 1998 \\
RV Belgica (Belgium) & BG 98/15 & 14 June 1998 to 14 July 1998 \\
RRS Charles Darwin (United Kingdom) & CD 114 & 29 July 1998 to 24 Aug. 1998 \\
RV Meteor (Germany) & M43/2 & 28 Dec. 1999 to 14 Jan. 1999 \\
RV Belgica (Belgium) & BG 99/19 & 30 Aug. 1999 to 21 Sept. 1999 \\
\hline
\end{tabular}

and Le Cann, 1990]. The slope current brings subtropical ENAW into the study zone separating shelf waters from offshore subpolar ENAW by a downwelling front. Little inorganic carbon data have been reported in the area [Fraga et al., 1992; Alvarez-Salgado et al., 1993; Doval et al., 1997]; however, south of the Galician coast, off the Portuguese coast between $39.8^{\circ}$ and $41.8^{\circ} \mathrm{N}$, ÁlvarezSalgado et al. [1997] and Pérez et al. [1999] have reported surface $p \mathrm{CO}_{2}$ data with values ranging between 320 and $460 \mu \mathrm{atm}$. In this area the spatial and seasonal variability is imposed by the input of $\mathrm{CO}_{2}$-rich waters from upwelling, primary production, the fresh water input of the Minho and Douro Rivers, and the poleward slope current during the downwelling season.

[6] In the present work, we report and discuss dissolved inorganic carbon data collected from 1997 to 1999, off the Galician coast, covering both upwelling (summer) and downwelling (winter) conditions, as a contribution to the OMEX II project.

\section{Material and Methods}

[7] Data were obtained off the Galician coast (Figure 1) during six cruises (Table 1). Underway parameters (seawater $p \mathrm{CO}_{2}$, salinity, and in situ temperature) were sampled with a frequency of $1 \mathrm{~min}$ from the nontoxic seawater supply of the ship (pump inlet at a depth of $-2.5 \mathrm{~m}$ ). A nondispersive infrared gas analyzer (Li-cor ${ }^{\circledR}$ LI-6262) was used to measure $p \mathrm{CO}_{2}$ in wet air equilibrated with seawater. Before $1998, p \mathrm{CO}_{2}$ was measured in equilibrated air dried with Drierite ${ }^{\mathbb{R}}$, and the data were converted into wet air using the algorithms proposed by Department of Energy [1994]. The Li-cor was calibrated daily using three dry gas standards: pure nitrogen (0.0 ppm; Air Liquide Belgium) and two gas mixtures with a $\mathrm{CO}_{2}$ molar fraction of $351.0 \mathrm{ppm}$ (Air Liquide Belgium) and 360.5 ppm (National Oceanic and Atmospheric Administration (NOAA)). The temperature at the outlet of the equilibrator was monitored with a platinum resistance thermometer (PT100, METROHM ${ }^{\mathrm{R}}$ ) with an estimated accuracy of $\pm 0.05^{\circ} \mathrm{C}$, and the $p \mathrm{CO}_{2}$ values are corrected for the temperature difference between in situ seawater and water in the equilibrator, using the algorithm proposed by Copin-Montégut [1988]. The offset in temperature was typically $\sim 0.5^{\circ} \mathrm{C}$. The accuracy of the $p \mathrm{CO}_{2}$ measurement by equilibration is estimated to $\pm 2 \mu \mathrm{atm}$ (cumulated errors on temperature correction and instrument calibration). For further details on the equilibrator design and performance tests, refer to Frankignoulle et al. [2001]. A second Li-cor was used to measure atmospheric $p \mathrm{CO}_{2}$ sampled at the bow of the ship at $\sim 10 \mathrm{~m}$ height. Total alkalinity (TAlk) was determined using the classical Gran electrotitration method on $100 \mathrm{~mL} \mathrm{GF} / \mathrm{F}$ filtered samples. The reproducibility of TAlk measurements performed on board is $\pm 4 \mu \mathrm{mol} \mathrm{kg}{ }^{-1}$. The measurement of $\mathrm{pH}$ was obtained using a Ross combination electrode $\left(\mathrm{ORION}^{\mathrm{R}}\right)$, calibrated on the total hydrogen ion concentration scale (mol kg SW${ }^{-1}$ ), using the TRIS (2-amino-2-hydroxymethyl1,3-propanediol) and AMP (2-aminopyridine) buffers proposed by Dickson [1993]. The reproducibility of $\mathrm{pH}$ measurement is estimated to be $\pm 0.004 \mathrm{pH}$ units. Total dissolved inorganic carbon (DIC) was calculated from the $\mathrm{pH}$ and TAlk measurements with the dissociation constants of carbonic acid from Roy et al. [1993], the borate molality obtained from the Culkin [1965] ratio to salinity, the dissociation constant of boric acid from Dickson [1990], and the carbon dioxide solubility coefficient of Weiss [1974]. The accuracy of DIC and $p \mathrm{CO}_{2}$ computed from the $\mathrm{pH}-$ TAlk couple are estimated to $\pm 5 \mu \mathrm{mol} \mathrm{kg} \mathrm{kg}^{-1}$ and $\pm 5 \mu \mathrm{atm}$, respectively. Dissolved oxygen concentration was measured by the Winkler method using a potentiometric end point determination with an estimated accuracy of $\pm 2 \mu \mathrm{mol} \mathrm{kg} \mathrm{kg}^{-1}( \pm 0.5 \%$ of level of saturation). The oxygen saturation level (percent $\mathrm{O}_{2}$ ) is calculated from the observed concentration of dissolved $\mathrm{O}_{2}$ and the concentration of $\mathrm{O}_{2}$ at saturation using the algorithm proposed by Benson and Krause [1984]. Salinity and in situ temperature were measured using a SeaBird ${ }^{\mathbb{R}}$ SBE21 (Belgica and Meteor) and a Falmouth Scientific Instruments ${ }^{\mathrm{B}}$ (Charles Darwin). Vertical profile data were obtained from a 12-bottle rosette coupled to a conductivity-temperature-depth (CTD) profiler (SeaBird SBE19). During all OMEX II cruises the salinity data were calibrated by British Oceanographic Data Centre (BODC) from discrete salinity samples analyzed with an AUTOSAL ${ }^{\mathbb{R}}$ salinometer. The estimated errors on salinity and in situ temperature measurements are \pm 0.05 and $\pm 0.01^{\circ} \mathrm{C}$, respectively.

[8] The upwelling index $\left(\mathrm{m}^{3} \mathrm{~s}^{-1} \mathrm{~km}^{-1}\right.$ of coast) gives an estimation of the flow of upwelled water per kilometer of coast. Strong positive values $\left(>1000 \mathrm{~m}^{3} \mathrm{~s}^{-1} \mathrm{~km}^{-1}\right.$ of coast $)$ correspond to active upwelling, and low values correspond to upwelling relaxation, while strong negative values (less than $-1000 \mathrm{~m}^{3} \mathrm{~s}^{-1} \mathrm{~km}^{-1}$ of coast) correspond to downwelling conditions. These data were obtained from NOAA Pacific Fisheries Environmental Laboratory. At $42^{\circ} \mathrm{N}, 9^{\circ} \mathrm{E}$, estimates of Ekman offshore transport were derived according to Bakun's method [Schwing et al., 1996] from geostrophic wind fields calculated from Fleet Numerical Meteorology and Oceanography Center (FNMOC) synoptic pressure fields.

\section{Results and Discussion}

\subsection{Spatial and Temporal Variability of $\mathrm{pCO}_{2}$ During the Upwelling Season}

3.1.1. Temperature distributions and upwelling intensity. [9] Upwelling occurred during all four summer cruises but with a variable intensity, except for the first leg of the cruise of the September 1999 cruise that corresponded to a distinct upwelling relaxation event (see temperature signature in Figures 2 and 3). The June 1997 cruise corresponded to the transition between upwelling relaxation and active upwelling conditions, the latter being only observed toward the end of the cruise. Indeed, the cold upwelled water was confined to a near-shore and narrow band (Figure 2), and prior to the cruise and during the first half of the cruise, wind speed showed a relatively low northerly component $\left(\leq 5 \mathrm{~m} \mathrm{~s}^{-1}\right)$, while upwelling index values increased at the middle of the cruise and indicate moderate upwelling conditions prior and at the start of the cruise $\left(\leq 1000 \mathrm{~m}^{3} \mathrm{~s}^{-1} \mathrm{~km}^{-1}\right.$ of coast) (Figure 4). The June 1998 and August 1998 cruises corresponded to strong upwelling events, characterized by high values of upwelling index $(\geq 1000$ $\mathrm{m}^{3} \mathrm{~s}^{-1} \mathrm{~km}^{-1}$ of coast) and northerly wind component values that 

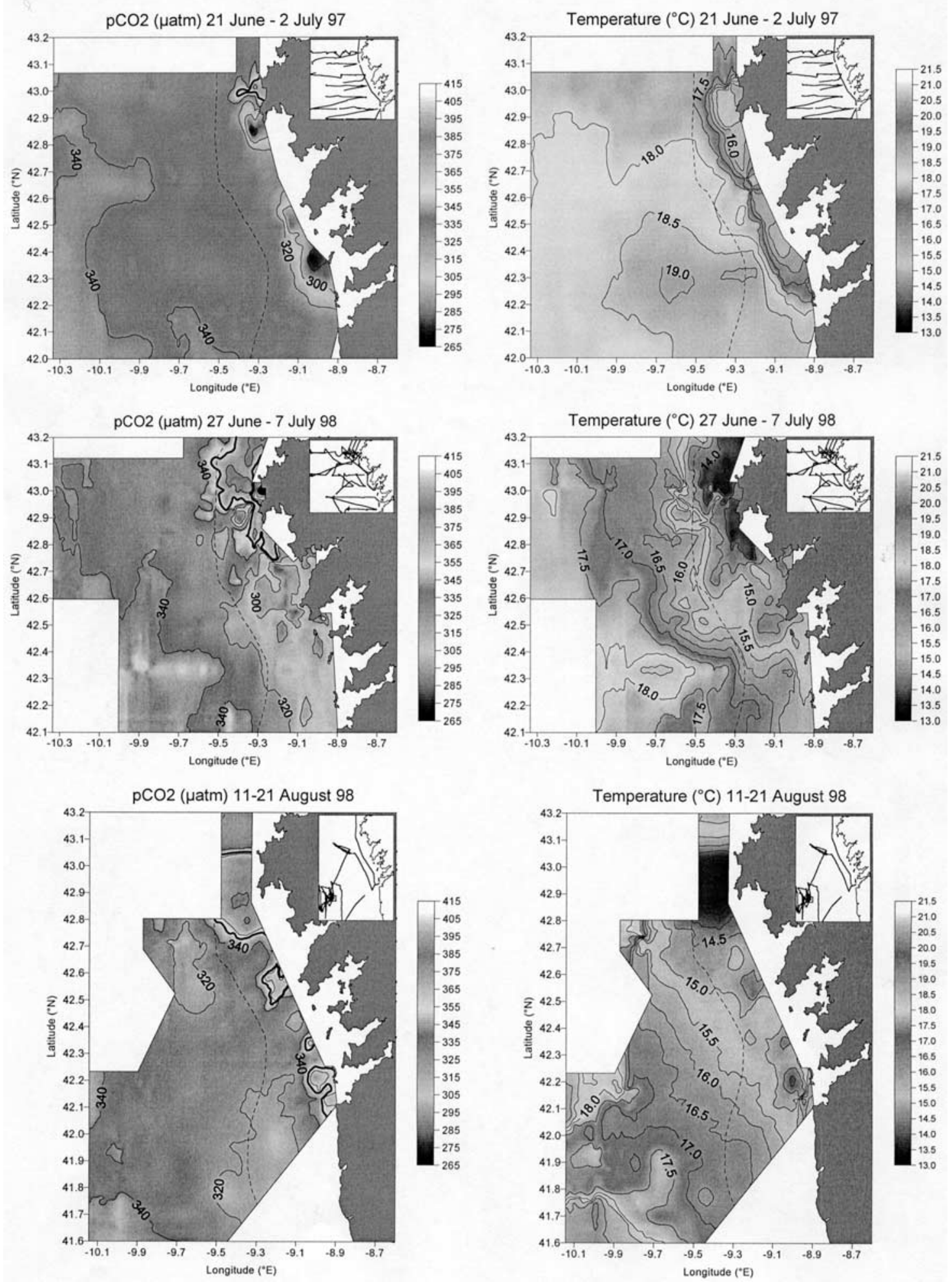

Figure 2. Surface water distributions of $\mathrm{pCO}_{2}$ ( $\left.\mu \mathrm{atm}\right)$ and temperature $\left({ }^{\circ} \mathrm{C}\right)$ in June 1997, June 1998, and August 1998. The dashed line corresponds to the $200 \mathrm{~m}$ isobath. The thick line corresponds to atmospheric $p \mathrm{CO}_{2}$. See color version of this figure at back of this issue.

are high throughout both cruises and are higher than the values prior to the cruises (Figure 4). The cold upwelled water is not confined near the shore and extents beyond the shelf break in relation to the formation of upwelling filaments (CTZ in Figure 1), as confirmed by sea surface temperature (SST) satellite images [Miller et al., 2001].

3.1.2. Spatial distribution of $\mathrm{pCO}_{2}$ (June 1997, June 1998, and August 1998 cruises). [10] There appear to be two distinct 

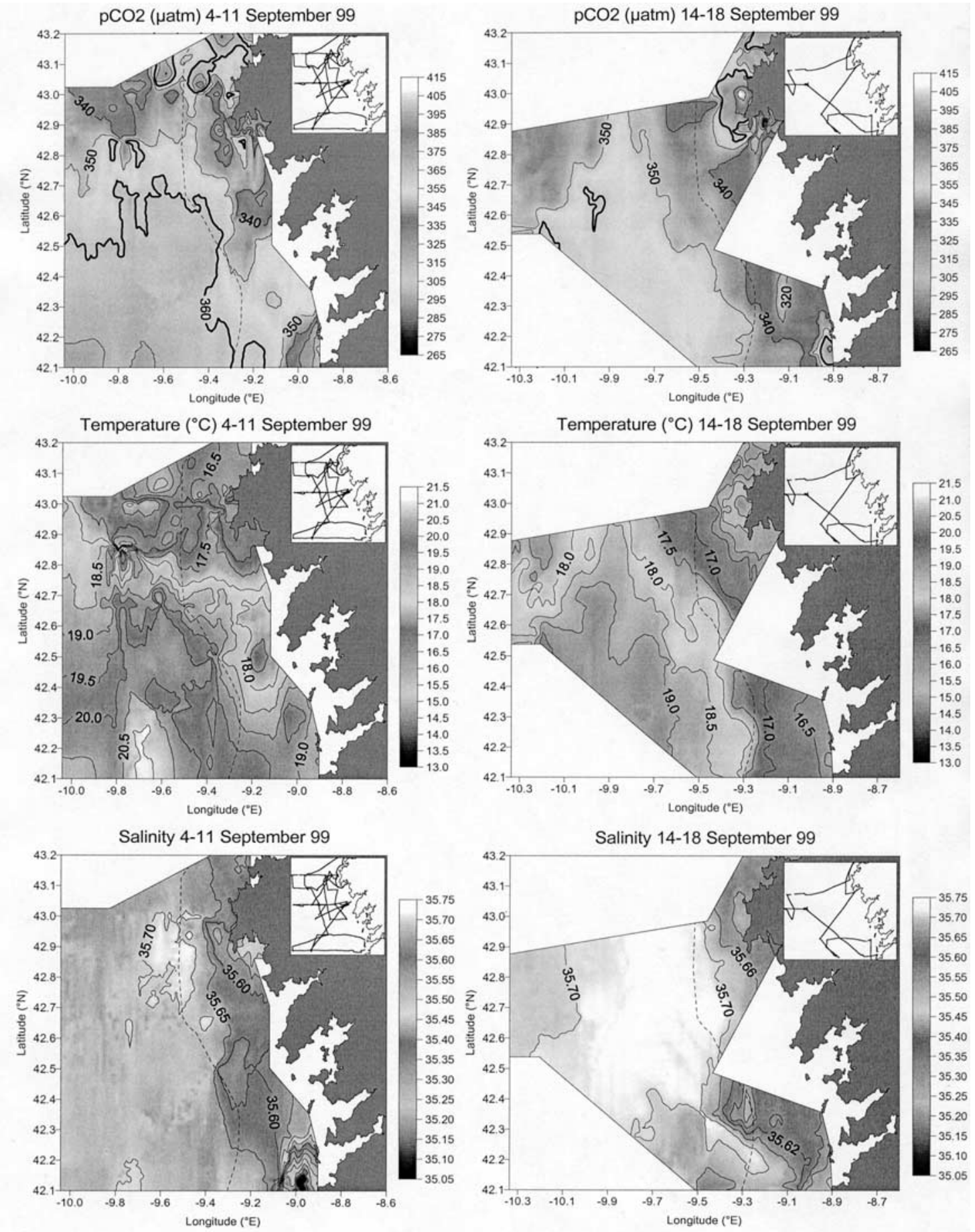

Figure 3. Surface water distributions of $p \mathrm{CO}_{2}(\mu \mathrm{atm})$, temperature $\left({ }^{\circ} \mathrm{C}\right)$, and salinity during the first and second legs of the September 1999 cruise. The dashed line corresponds to the $200 \mathrm{~m}$ isobath. The thick line corresponds to atmospheric $p \mathrm{CO}_{2}$. See color version of this figure at back of this issue.

hydrographic regions over the continental shelf: the Cape Finisterre area (CFA, Figure 1) and the Rías Baixas area (RBA, Figure 1). In the CFA, oversaturation of $\mathrm{CO}_{2}$ with respect to the atmosphere was observed during all cruises; however, its magnitude and spatial extension are related to the intensity of upwelling. For instance, during the June 1997 cruise (low upwelling conditions) the over- saturation of $\mathrm{CO}_{2}$ is confined to a small near-shore area, while during the June 1998 cruise (intense upwelling conditions) it extends to the shelf break. In the RBA, undersaturation of $\mathrm{CO}_{2}$ was systematically observed. Oversaturation of $\mathrm{CO}_{2}$ was only observed during the August 1998 and the second leg of the September 1999 cruises, within small patches over the near-shore continental shelf. 
21 June - 2 July 97

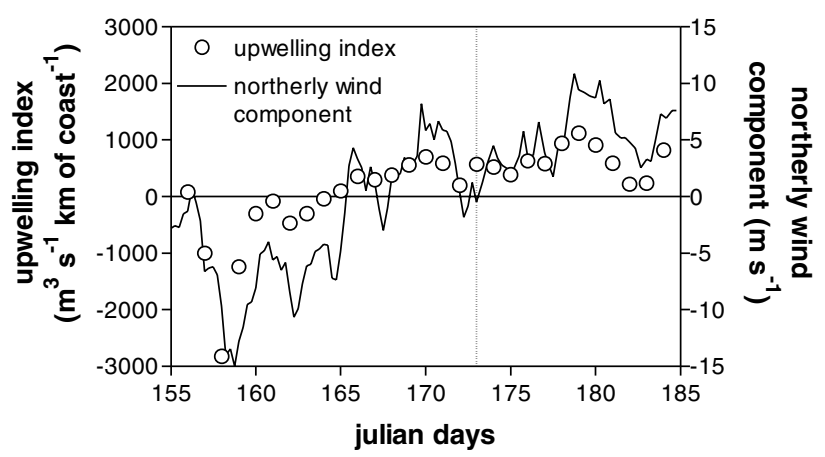

27 June - 7 July 98

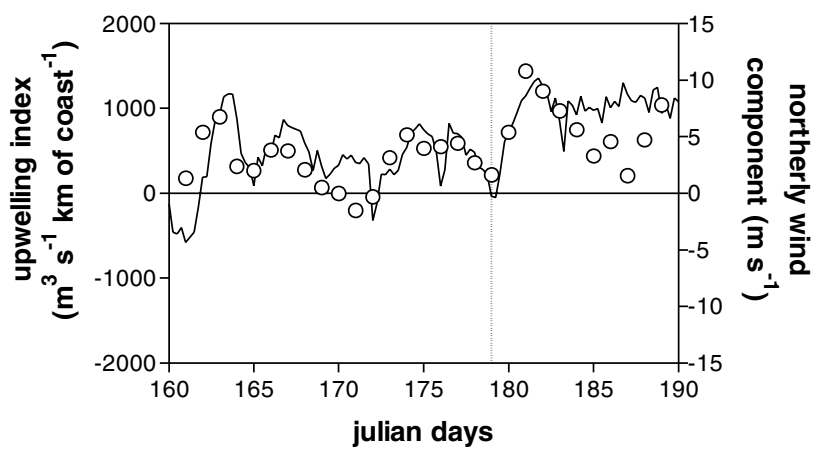

11 - 21 August 98

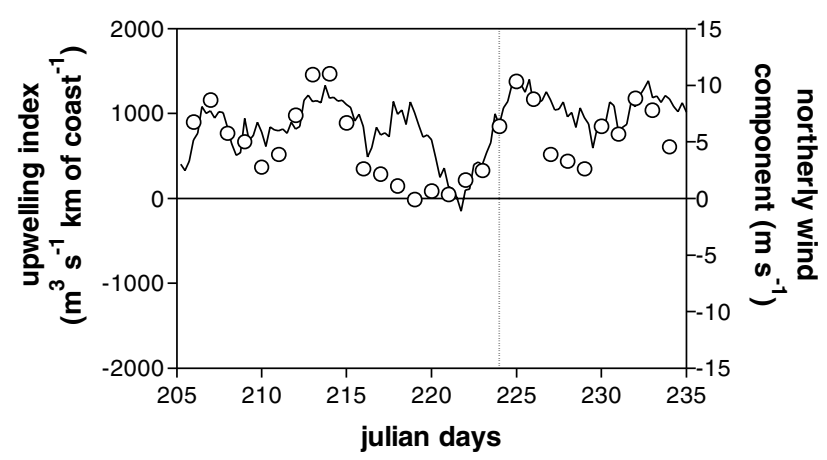

4 - 18 September 99

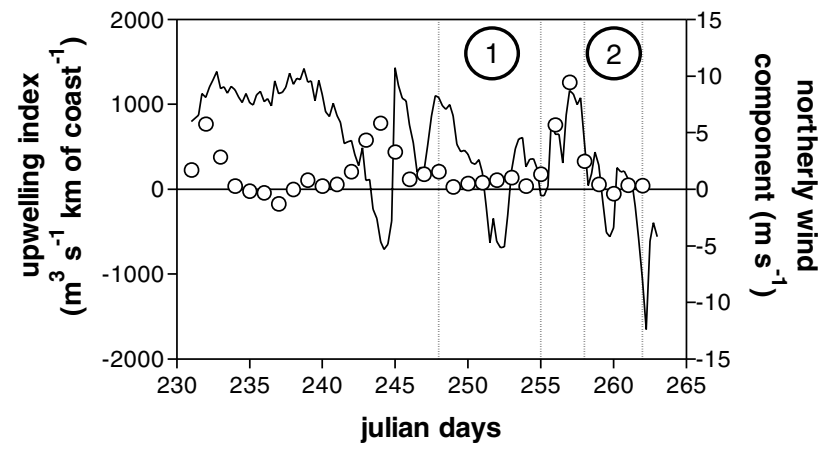

Figure 4. Distribution of the upwelling index $\left(\mathrm{m}^{3} \mathrm{~s}^{-1} \mathrm{~km}^{-1}\right.$ of coast) and northerly wind speed component (European Center for Medium Weather Forecast geostrophic wind speed calculated from pressure fields). Vertical dashed line corresponds to the start of the cruise and 1 and 2 refer to the first and second legs of the September 1999 cruise.

[11] These systematic structures in the distribution of $p \mathrm{CO}_{2}$ in the CFA and the RBA are discussed in detail by Borges and Frankignoulle [2002] in relation to the effect of outwelling from the rías and the width of the continental shelf. The outwelling from the rías of warm and strongly $\mathrm{CO}_{2}$ undersaturated water affects significantly the adjacent inner continental shelf but to a much lesser extent the outer continental shelf. In the CFA the continental shelf is narrower than in the RBA, so that the ratio between the surface area and the length of the shelf break is lower in the CFA. Because the volume of water that can be upwelled on to the shelf is limited by the length of the shelf break, this implies that the ratio between the volume of upwelled water to the volume of water on the shelf is higher in the CFA. This in turn affects surface parameters such as temperature and DIC as investigated by Borges and Frankignoulle [2002] with simple simulations that show that the lower temperature and higher $p \mathrm{CO}_{2}$ values in the Cape Finisterre area can, to some extent, be explained by this topographic feature.

3.1.3. Short-term upwelling-controlled variability of $p \mathrm{CO}_{2}$ in shelf waters (September 1999 cruise). [12] During the September 1999 cruise, two distinct hydrographic situations were encountered. The first leg of the cruise corresponded to an upwelling relaxation event, but during the port call an upwelling event occurred (Figure 4). According to Alvarez-Salgado et al. [1993], surface water parameters respond to the onset of upwelling-favorable winds with a time lag of 2-3 days. So during the second leg of the cruise the distribution of surface parameters was affected by the upwelling event that occurred during the port call as shown by the significant decrease of temperature (Figure 3).
Also, in front of the Ría of Vigo, there is a distinct signal in salinity of outwelling during the first leg that is much less marked during the second leg. This is also consistent with the transition from upwelling relaxation to active upwelling conditions according to Borges and Frankignoulle [2001]. By the end of the second leg, upwelling index and the northerly wind speed component indicate upwelling relaxation-favorable conditions. However, most of the surface sampling was carried out during the first 2 days of the second leg, and if surface parameters respond with a time lag of $2-3$ days, then we can consider this leg of the cruise as representative of an active upwelling event.

[13] A near-shore station in the CFA was sampled three consecutive times during the cruise (Figure 5) and the temperature, percent $\mathrm{O}_{2}$, and $\mathrm{DIC}_{35}$ profiles clearly show the evolution from moderate stratification to upwelling conditions. The evolution of $p \mathrm{CO}_{2}$ in surface seawater (underway measurements) is consistent with the one of $\mathrm{DIC}_{35}$, and the values are, sequentially, 344, 360, and $416 \mu \mathrm{atm}$. It is interesting to note that the $p \mathrm{CO}_{2}$ change is $\sim 3 \mu \mathrm{atm} \mathrm{d}^{-1}$ between the 5 and the 11 September, while it is much faster, $\sim 19 \mu \mathrm{atm} \mathrm{d}^{-1}$, between the 11 and the 14 September. Thus the transition from upwelling relaxation $\left(\mathrm{CO}_{2}\right.$ undersaturation) and active upwelling $\left(\mathrm{CO}_{2}\right.$ oversaturation) takes only a few days, showing how dynamic coastal upwelling systems are from the point of view of dissolved inorganic carbon.

3.1.4. Short-term temperature-controlled variability of pCO$_{2}$ in off-shelf waters (September 1999 cruise). [14] During the September 1999 cruise, temperature and $p \mathrm{CO}_{2}$ in the off- 
Table 2. Mean Wind Speed $u_{10}$, Seawater Temperature, Air-Sea Gradient of $\mathrm{CO}_{2}\left(\Delta p \mathrm{CO}_{2}\right)$, and Air-Sea CO Fluxes Computed According to Five Parameterizations of $\mathrm{CO}_{2}$ Exchange Coefficient in Four Hydrographic Regions ${ }^{\mathrm{a}}$

\begin{tabular}{|c|c|c|c|c|c|c|c|c|c|}
\hline Cruise & Region & $\begin{array}{l}u_{10} \\
\mathrm{~m} \mathrm{~s}^{-1} \\
\end{array}$ & $\begin{array}{c}\text { Temperature, } \\
{ }^{\circ} \mathrm{C} \\
\end{array}$ & $\begin{array}{c}\Delta p \mathrm{CO}_{2}, \\
\mu \mathrm{atm}\end{array}$ & 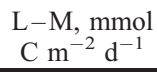 & $\begin{array}{c}\mathrm{T}, \mathrm{mmol} \\
\mathrm{C} \mathrm{m}^{-2} \mathrm{~d}^{-1} \\
\end{array}$ & $\begin{array}{l}\mathrm{W}, \mathrm{mmol} \mathrm{C} \\
\mathrm{m}^{-2} \mathrm{~d}^{-1}\end{array}$ & $\begin{array}{c}\mathrm{W}-\mathrm{M}, \mathrm{mmol} \mathrm{C} \\
\mathrm{m}^{-2} \mathrm{~d}^{-1}\end{array}$ & $\underset{\mathrm{m}^{-2} \mathrm{~d}^{-1}}{\mathrm{~N}, \mathrm{mmol} \mathrm{C}}$ \\
\hline 21 June to 2 July 1997 & CFA & 7 & 16.6 & -27 & $-2.2( \pm 0.6)$ & $-4.9( \pm 0.9)$ & $-3.6( \pm 1.2)$ & $-2.9( \pm 0.8)$ & $-3.0( \pm 0.7)$ \\
\hline 21 June to 2 July 1997 & RBA & 7 & 17.7 & -36 & $-3.0( \pm 0.8)$ & $-6.7( \pm 1.2)$ & $-4.9( \pm 1.5)$ & $-3.9( \pm 1.0)$ & $-4.1( \pm 0.9)$ \\
\hline 21 June to 2 July 1997 & OSA & 7 & 18.2 & -23 & $-2.0( \pm 0.6)$ & $-4.4( \pm 0.8)$ & $-3.2( \pm 1.1)$ & $-2.5( \pm 0.7)$ & $-2.7( \pm 0.7)$ \\
\hline 27 June to 7 July 1998 & CFA & 10 & 14.1 & -1 & $-0.1( \pm 0.3)$ & $-0.1( \pm 0.5)$ & $-0.1( \pm 0.6)$ & $-0.1( \pm 0.5)$ & $-0.1( \pm 0.4)$ \\
\hline 27 June to 7 July 1998 & RBA & 10 & 15.3 & -46 & $-6.9( \pm 1.3)$ & $-13.9( \pm 2.6)$ & $-12.1( \pm 2.6)$ & $-13.8( \pm 3.1)$ & $-9.7( \pm 1.9)$ \\
\hline 27 June to 7 July 1998 & $\mathrm{CTZ}$ & 10 & 17.2 & -27 & $-4.2( \pm 0.9)$ & $-8.4( \pm 1.7)$ & $-7.3( \pm 1.8)$ & $-8.3( \pm 2.0)$ & $-5.9( \pm 1.3)$ \\
\hline 27 June to 7 July 1998 & OSA & 10 & 17.8 & -18 & $-2.6( \pm 0.7)$ & $-5.3( \pm 1.3)$ & $-4.5( \pm 1.3)$ & $-5.2( \pm 1.4)$ & $-3.7( \pm 1.0)$ \\
\hline 11-21 August 1998 & CFA & 10 & 14.1 & +2 & $+0.3( \pm 0.4)$ & $+0.6( \pm 0.6)$ & $+0.5( \pm 0.7)$ & $+0.6( \pm 0.6)$ & $+0.4( \pm 0.5)$ \\
\hline 11-21 August 1998 & RBA & 10 & 14.8 & -14 & $-2.3( \pm 0.7)$ & $-4.5( \pm 1.2)$ & $-4.1( \pm 1.3)$ & $-4.9( \pm 1.4)$ & $-3.3( \pm 0.9)$ \\
\hline $11-21$ August 1998 & $\mathrm{CTZ}$ & 10 & 15.8 & -28 & $-4.5( \pm 1.0)$ & $-9.0( \pm 1.9)$ & $-8.1( \pm 1.9)$ & $-9.7( \pm 2.4)$ & $-6.5( \pm 1.4)$ \\
\hline $11-21$ August 1998 & OSA & 10 & 18.2 & -14 & $-2.3( \pm 0.7)$ & $-4.7( \pm 1.2)$ & $-4.2( \pm 1.3)$ & $-5.0( \pm 1.4)$ & $-3.3( \pm 0.9)$ \\
\hline 4-11 September 1999 & CFA & 4 & 16.7 & -14 & $-0.3( \pm 0.1)$ & $-0.8( \pm 0.2)$ & $-0.8( \pm 0.3)$ & $-0.4( \pm 0.1)$ & $-0.6( \pm 0.2)$ \\
\hline 4-11 September 1999 & RBA & 4 & 18.4 & -18 & $-0.4( \pm 0.1)$ & $-1.0( \pm 0.2)$ & $-1.1( \pm 0.4)$ & $-0.5( \pm 0.1)$ & $-0.8( \pm 0.2)$ \\
\hline 4-11 September 1999 & $\mathrm{CTZ}$ & 4 & 16.9 & -15 & $-0.4( \pm 0.1)$ & $-0.8( \pm 0.2)$ & $-0.9( \pm 0.3)$ & $-0.4( \pm 0.1)$ & $-0.6( \pm 0.2)$ \\
\hline 4-11 September 1999 & OSA & 4 & 19.6 & +1 & $0.0( \pm 0.1)$ & $0.0( \pm 0.1)$ & $0.0( \pm 0.1)$ & $0.0( \pm 0.0)$ & $0.0( \pm 0.1)$ \\
\hline 14-18 September 1999 & CFA & 7 & 15.9 & -1 & $-0.1( \pm 0.2)$ & $-0.2( \pm 0.2)$ & $-0.2( \pm 0.4)$ & $-0.2( \pm 0.2)$ & $-0.2( \pm 0.2)$ \\
\hline 14-18 September 1999 & RBA & 7 & 16.8 & -19 & $-1.4( \pm 0.4)$ & $-3.1( \pm 0.6)$ & $-2.7( \pm 0.9)$ & $-2.4( \pm 0.5)$ & $-2.1( \pm 0.5)$ \\
\hline 14-18 September 1999 & $\mathrm{CTZ}$ & 7 & 17.3 & -16 & $-1.2( \pm 0.4)$ & $-2.7( \pm 0.6)$ & $-2.3( \pm 0.8)$ & $-2.0( \pm 0.4)$ & $-1.8( \pm 0.4)$ \\
\hline 14-18 September 1999 & OSA & 7 & 18.5 & -6 & $-0.4( \pm 0.2)$ & $-0.9( \pm 0.3)$ & $-0.8( \pm 0.5)$ & $-0.7( \pm 0.2)$ & $-0.6( \pm 0.3)$ \\
\hline 6-16 January 1998 & $\mathrm{CFA}+\mathrm{RBA}$ & 11 & 15.1 & -28 & $-4.8( \pm 1.0)$ & $-9.3( \pm 1.9)$ & $-8.2( \pm 1.9)$ & $-9.8( \pm 2.4)$ & $-6.6( \pm 1.5)$ \\
\hline 6-16 January 1998 & OSA & 11 & 14.9 & -21 & $-3.5( \pm 0.8)$ & $-6.8( \pm 1.5)$ & $-6.0( \pm 1.5)$ & $-7.2( \pm 1.9)$ & $-4.8( \pm 1.2)$ \\
\hline
\end{tabular}

${ }^{\mathrm{a}}$ Abbreviations are as follows: L-M, Liss and Merlivat [1986]; T, Tans et al. [1990]; W, Wanninkhof [1992]; W-M, Wanninkhof and McGillis [1999]; N, Nightingale et al. [2000]; Cape Finisterre area, CFA; Rías Baixas area, RBA; coastal transition zone, CTZ; offshore area, OSA. Regions are shown in Figure 1; the data from the January 1998 cruise were not separated into the CFA and RBA because the difference between these two hydrographic areas is related to upwelling, so the fluxes were directly computed for the whole of the continental shelf (CFA plus RBA). The values of atmospheric $p \mathrm{CO}_{2}$ from Barrow [Keeling and Whorf, 1999] were used for the June 1997 and January 1998 cruises when direct atmospheric $p \mathrm{CO}_{2}$ measurements were not available. The flux computations were made from interpolated fields of $\Delta p \mathrm{CO}_{2}$ and temperature on a $0.02^{\circ} \times 0.02^{\circ}$ grid and from the series of 3 hourly averages of the ship-borne wind speed measurements for the full duration of the cruise. The final flux value is the mean of fluxes computed from the series of 3 hourly average wind speeds. The $p \mathrm{CO}_{2}$ distribution is assumed to remain unchanged during the duration of the cruise, meaning that the map of $p \mathrm{CO}_{2}$ for a given cruise is considered synoptic. The incertitude on the flux was computed from estimated accuracy on $\Delta p \mathrm{CO}_{2}( \pm 2 \mu \mathrm{atm})$, temperature $\left( \pm 0.01^{\circ} \mathrm{C}\right)$ and wind speed $( \pm 10 \%)$.

shelf waters decreased from the first to the second leg with a shift from oversaturation to undersaturation of $\mathrm{CO}_{2}$ (Figures 3 and 6). The evolution of temperature profiles at two nearby stations sampled during the first and the second leg, respectively, clearly show the transition from important surface stratification to a homogeneous mixed layer (Figure 6, plot A). The deepening of the thermocline and concomitant mixing of surface and deeper waters can be related to the high wind speeds associated with the upwelling event that occurred during the port call. The evolution of the vertical profiles of percent $\mathrm{O}_{2}$ and $\mathrm{DIC}_{35}$ also illustrates the effect of the mixing of surface water with deeper water (Figure 6, plots $\mathrm{B}$ and 6). However, the evolution of the $p \mathrm{CO}_{2}$ vertical profiles is inconsistent with the one of $\mathrm{DIC}_{35}$ and shows the opposite trend $\left(\mathrm{pCO}_{2}\right.$ values in the surface layer are lower during the second leg of the cruise). This can be explained by the effect of temperature on equilibrium constants of dissolved inorganic carbon and, in particular, on the solubility coefficient of $\mathrm{CO}_{2} \quad\left(p \mathrm{CO}_{2}\right.$ rises of $\sim 4 \%$ for a temperature increase of $1^{\circ} \mathrm{C}$ ). Indeed, the vertical profiles of $p \mathrm{CO}_{2}$ normalized to $17^{\circ} \mathrm{C}\left(p \mathrm{CO}_{2}\left(17^{\circ} \mathrm{C}\right)\right)$ are consistent with the ones of $\mathrm{DIC}_{35}$ (Figure 6, plot $\mathrm{G}$ ). The data points of $p \mathrm{CO}_{2}\left(17^{\circ} \mathrm{C}\right)$ from the second leg fall onto the curve of $p \mathrm{CO}_{2}\left(17^{\circ} \mathrm{C}\right)$ versus $\mathrm{DIC}_{35}$ from the first leg of the cruise, while this is not the case for $p \mathrm{CO}_{2}$ at in situ temperature (Figure 6, plots $\mathrm{F}$ and $\mathrm{G}$ ). We can conclude that the observed variation of $p \mathrm{CO}_{2}$ in surface waters is related to temperature change due to vertical mixing. Although the overall vertical distribution of parameters is related to biological activity, temperature change is also an important factor controlling surface $p \mathrm{CO}_{2}$ in the offshore waters of the studied site. Conversely, during strong upwelling relaxation events characterized by low wind speed (low turbulence) the warming up of surface water can induce oversaturation of $\mathrm{CO}_{2}$.

\subsection{Spatial and Temporal Variability of $p \mathrm{CO}_{2}$ During the Downwelling Season}

[15] During the January 1998 cruise the temperature and salinity distributions were controlled by two processes, the input of fresh water from the Rías Baixas and the poleward slope current (Figure 7). This surface residual current is characteristic of downwelling/ winter conditions and is directed northward, bringing into the region water of southern origin (subtropical ENAW [Frouin et al., 1990; Haynes and Barton, 1990; Stevens et al., 2000]). This induces along the shelf break a tongue of relatively warm $\left(15.0^{\circ}-15.6^{\circ} \mathrm{C}\right)$ and saline water $(35.9-36.0)$ compared to subpolar ENAW $\left(\sim 14.5^{\circ} \mathrm{C}\right.$ and $\left.\sim 35.85\right)$. The poleward current confines, on the continental shelf, the water from the Rías, creating a distinct patch of low salinity $(31.5-35.0)$ and cooler water $\left(13.7^{\circ}\right.$ $15.0^{\circ} \mathrm{C}$ ) (Figure 7 ).

[16] Undersaturation of $\mathrm{CO}_{2}$ was observed throughout the sampled region, and this can be related to the cooling of surface waters that lowers the $p \mathrm{CO}_{2}$ values. However, each water mass is characterized by a relatively specific $p \mathrm{CO}_{2}$ signal. The water mass related to the poleward current has lower $p \mathrm{CO}_{2}$ values $(335-340$ $\mu \mathrm{atm})$ than the subpolar ENAW (345-350 $\mu \mathrm{atm})$, but the lowest values of $p \mathrm{CO}_{2}$ were associated with the plume of the Rías Baixas (315-340 $\mu \mathrm{atm})$. River plumes are known to show a wide range of $p \mathrm{CO}_{2}$ values, but during winter they are frequently oversaturated in $\mathrm{CO}_{2}$ [Hoppema, 1991; Bakker et al., 1996; Frankignoulle et al., 1998; Brasse et al., 1999; Borges and Frankignoulle, 1999]. Unfortunately, no sampling was carried out within the Rías Baixas, 

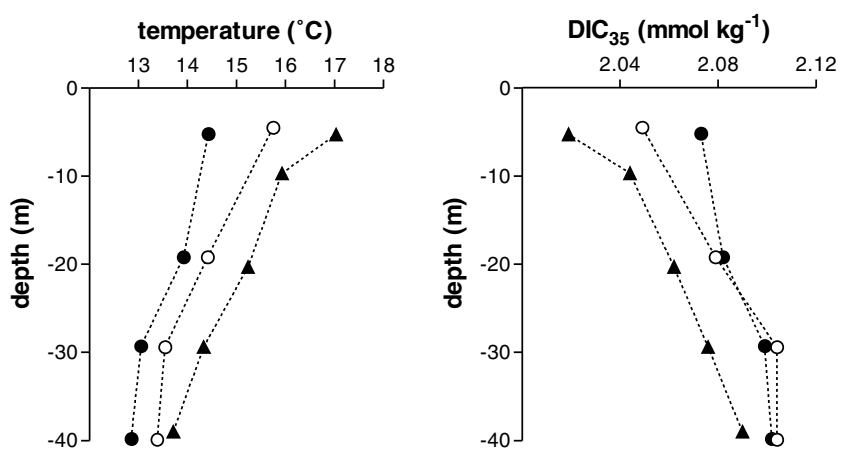

[17] The January 1999 cruise corresponded to atypical winter conditions according to the time series of SST satellite images that indicate intermittent upwelling events during fall 1998 and early winter 1999 [Miller et al., 2001]. This could explain why although the signature of the slope poleward current is apparent in the northsouth gradients of salinity, the patterns of temperature and $p \mathrm{CO}_{2}$ are not as clearly defined as in January 1998. The distribution of $p \mathrm{CO}_{2}$, in offshore waters, in January 1999 is consistent with one from 1998; that is, undersaturation of $\mathrm{CO}_{2}$ is related to temperature
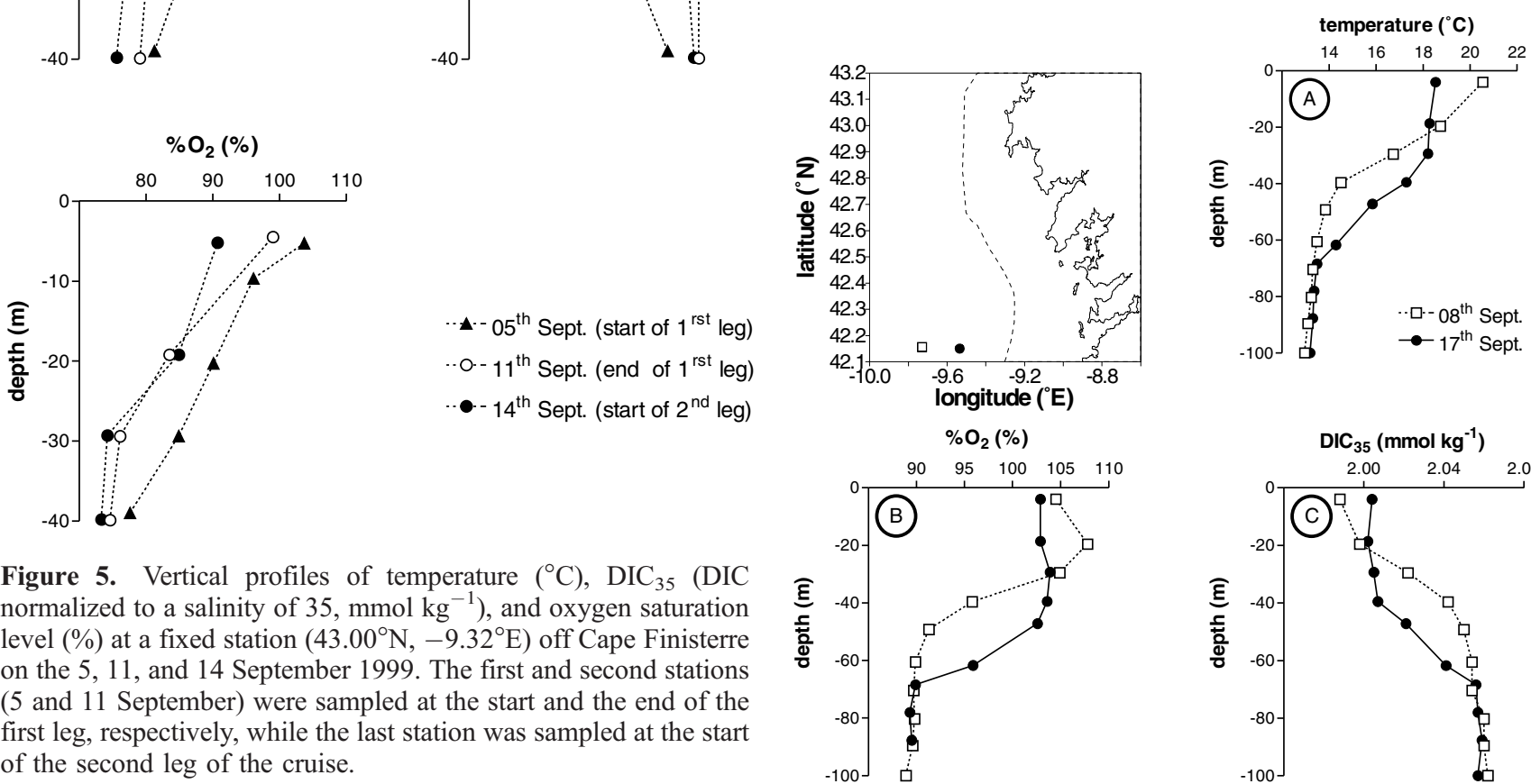

Figure 5. Vertical profiles of temperature $\left({ }^{\circ} \mathrm{C}\right.$ ), $\mathrm{DIC}_{35}$ (DIC normalized to a salinity of $\left.35, \mathrm{mmol} \mathrm{kg}^{-1}\right)$, and oxygen saturation level $(\%)$ at a fixed station $\left(43.00^{\circ} \mathrm{N},-9.32^{\circ} \mathrm{E}\right)$ off Cape Finisterre on the 5, 11, and 14 September 1999. The first and second stations (5 and 11 September) were sampled at the start and the end of the first leg, respectively, while the last station was sampled at the start of the second leg of the cruise.

so it is difficult to identify the processes that induced the undersaturation in the low-salinity waters over the continental shelf. The cooling of surface water is one possible mechanism, and it is clear that the low-salinity water over the shelf is colder than offshore waters. Furthermore, the mixed layer was shallower over the shelf ( $\sim 60 \mathrm{~m}$ ) than offshore $(\sim 120 \mathrm{~m})$, so that the surface water cooling would be expected to be more important over the shelf. Inorganic carbon fixation by phytoplankton could also affect to some extent surface water $p \mathrm{CO}_{2}$. A few gross primary production measurements were carried out during this cruise, and values are relatively low but not negligible: along the $42.7^{\circ} \mathrm{N}$ parallel, gross primary production rates were $\sim 20( \pm 4) \mathrm{mmol} \mathrm{C} \mathrm{m} \mathrm{d}^{-2}$ at the shelf break (approximately $-9.5^{\circ} \mathrm{E}$, water column depth $\sim 200 \mathrm{~m}$ ) and $\sim 10$ $( \pm 2) \mathrm{mmol} \mathrm{C} \mathrm{m} \mathrm{d}^{-2}$ in the adjacent off-shelf waters (approximately $-9.6^{\circ} \mathrm{E}$, water column depth $\sim 1000 \mathrm{~m}$ ) [Figueiras et al., 2001]. No measurements were carried out in the low-salinity waters over the shelf. However, along the same transect, the chlorophyll $a$ concentration was higher in the low-salinity waters over the shelf $\left(\sim 0.85( \pm 0.04) \mu \mathrm{g} \mathrm{L}^{-1}\right.$ at approximately $\left.-9.2^{\circ} \mathrm{E}\right)$ than at the shelf break $\left(\sim 0.40( \pm 0.01) \mu \mathrm{g} \mathrm{L}^{-1}\right.$ at approximately $\left.-9.5^{\circ} \mathrm{E}\right)$ and than in offshore waters $\left(\sim 0.25 \mu \mathrm{g} \mathrm{L}^{-1}( \pm 0.02)\right.$ at approximately $-10.3^{\circ} \mathrm{E}$ ) [Mantoura et al., 2001] (the error estimates on chlorophyll $a$ concentration are based on the precision of high-performance liquid chromatography (HPLC) pigment analysis of $\pm 5 \%$ given by Arar [1997]). This gradient in phytoplanktonic biomass could possibly be related to higher gross primary production rates over the shelf. Moreover, even if primary production rates were similar over the shelf and at the shelf break, the effect of phytoplanktonic inorganic carbon assimilation would be more important over the shelf owing to shallower mixed layer.
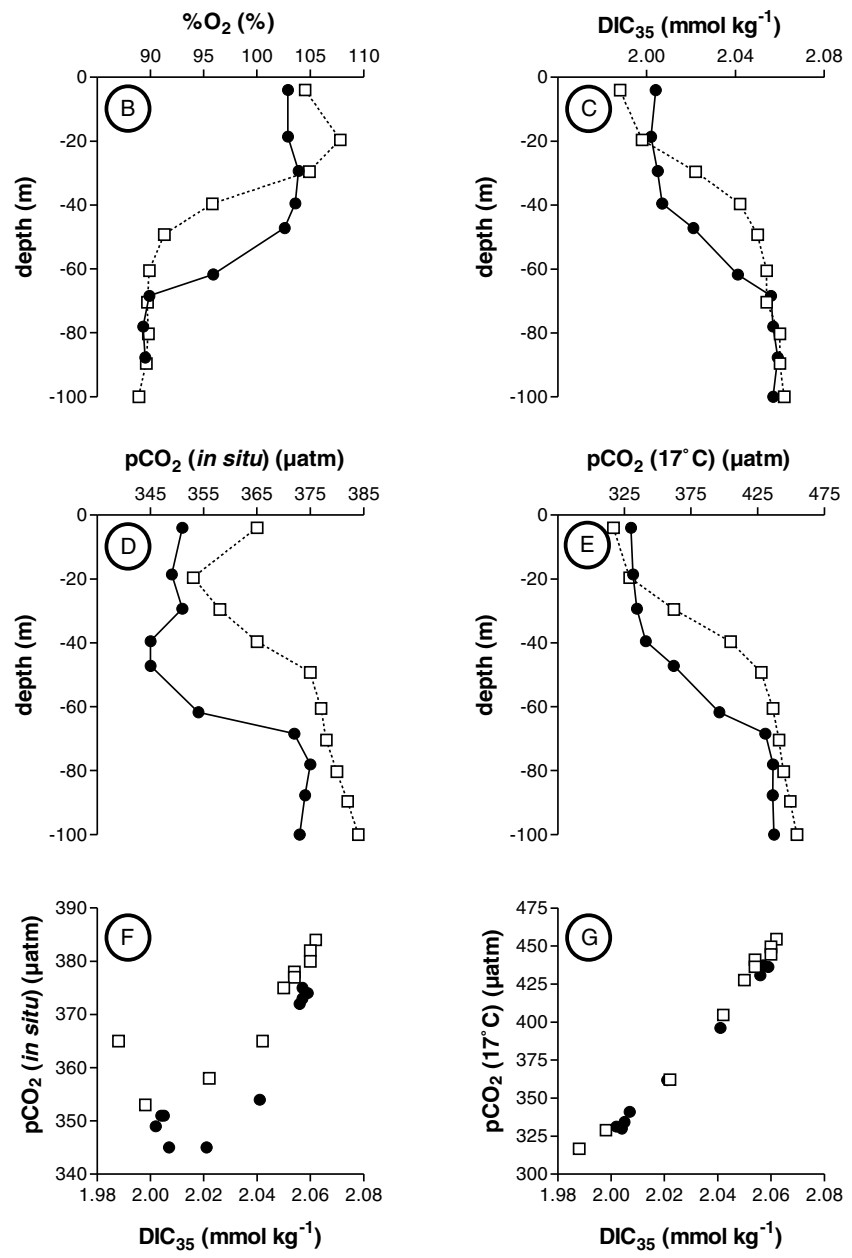

Figure 6. Vertical profiles of temperature $\left({ }^{\circ} \mathrm{C}\right)$, oxygen saturation level (\%), $\mathrm{DIC}_{35}\left(\mathrm{mmol} \mathrm{kg}^{-1}\right), p \mathrm{CO}_{2}(\mu \mathrm{atm})$, and $p \mathrm{CO}_{2}$ normalized to $17^{\circ} \mathrm{C}(\mu \mathrm{atm})$ at two stations shown in map, sampled on the 8 and 17 September 1999 and plots of $p \mathrm{CO}_{2}$ and $p \mathrm{CO}_{2}$ normalized to $17^{\circ} \mathrm{C}$ versus $\mathrm{DIC}_{35}$. The two stations were sampled during the first and second leg of the cruise, respectively (see also Figure 3 ).

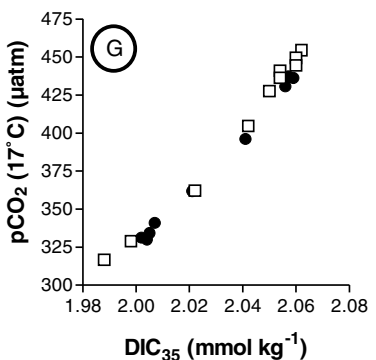



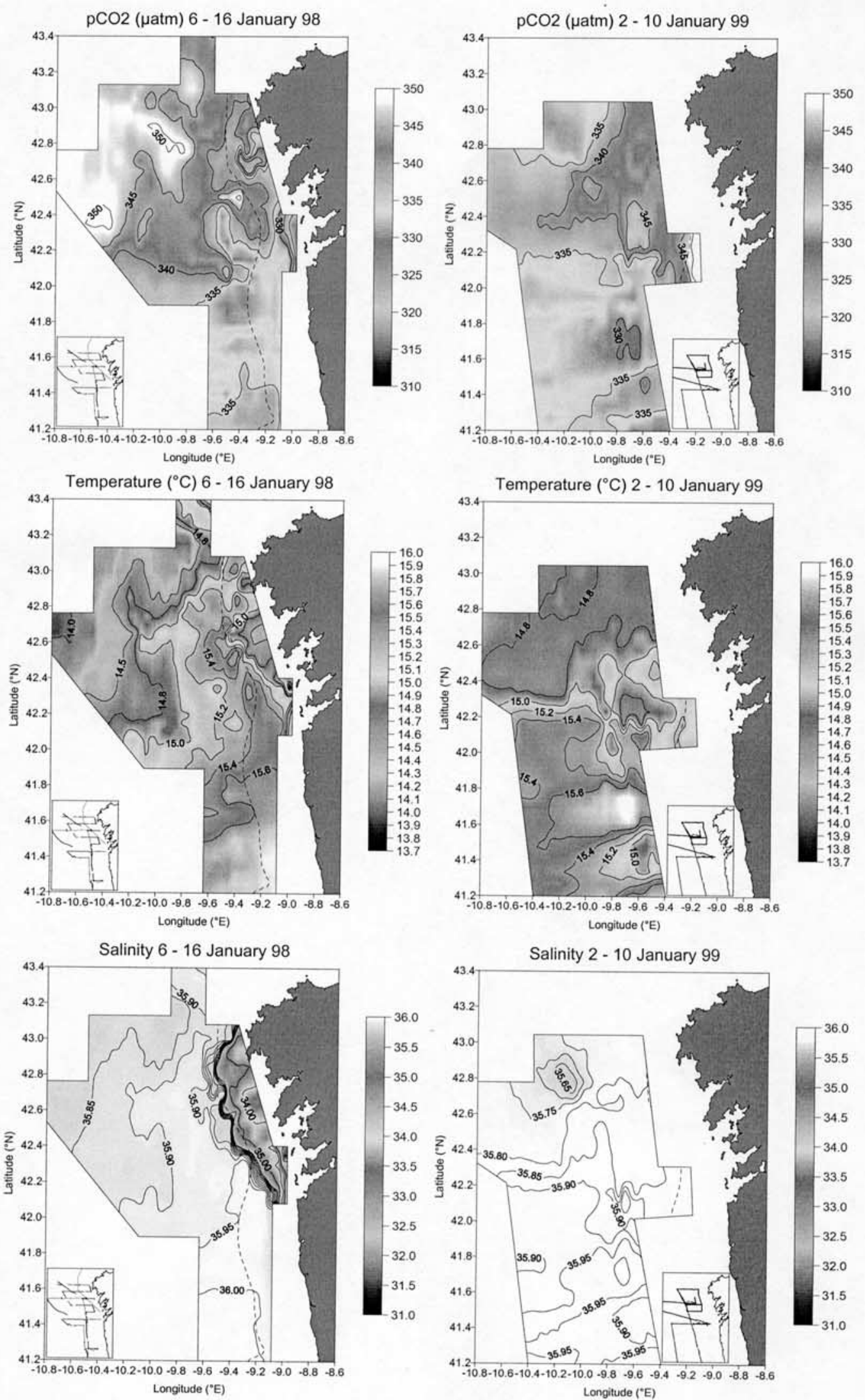

Figure 7. Surface water distributions of $p \mathrm{CO}_{2}$ ( $\left.\mu \mathrm{atm}\right)$, temperature $\left({ }^{\circ} \mathrm{C}\right)$, and salinity in January 1998 and 1999 . The dashed line corresponds to the $200 \mathrm{~m}$ isobath. The thick line corresponds to atmospheric $p \mathrm{CO}_{2}$. See color version of this figure at back of this issue. 
Table 3. Integrated Values Per Cruise, Per Season, and Annually of the Air-Sea Gradient of $\mathrm{CO}_{2}\left(\Delta p \mathrm{CO}_{2}\right)$ and $\mathrm{Air}-\mathrm{Sea} \mathrm{CO}_{2}$ Fluxes Computed According to Five Parameterizations of $\mathrm{CO}_{2}$ Exchange Coefficient Over the Continental Shelf (CFA Plus RBA) and in OffShelf Waters (OSA plus CTZ) ${ }^{\mathrm{a}}$

\begin{tabular}{|c|c|c|c|c|c|c|c|}
\hline Cruise & Region & $\begin{array}{c}\Delta p \mathrm{CO}_{2} \\
\mu \text { atm }\end{array}$ & $\begin{array}{c}\mathrm{L}-\mathrm{M}, \mathrm{mmol} \\
\mathrm{C} \mathrm{\textrm {m } ^ { - 2 }} \mathrm{d}^{-1}\end{array}$ & $\begin{array}{c}\mathrm{T}, \mathrm{mmol} \\
\mathrm{C} \mathrm{m}^{-2} \mathrm{~d}^{-1}\end{array}$ & 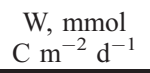 & $\begin{array}{c}\mathrm{W}-\mathrm{M}, \mathrm{mmol} \\
\mathrm{C} \mathrm{\textrm {m } ^ { - 2 }} \mathrm{d}^{-1}\end{array}$ & 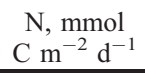 \\
\hline 21 June to 2 July $1997^{\mathrm{b}}$ & $\mathrm{CFA}+\mathrm{RBA}$ & -34 & $-2.9( \pm 0.7)$ & $-6.4( \pm 1.1)$ & $-4.7( \pm 1.5)$ & $-3.7( \pm 1.0)$ & $-3.9( \pm 0.9)$ \\
\hline 21 June to 2 July $1997^{b}$ & OSA & -23 & $-2.0( \pm 0.6)$ & $-4.4( \pm 0.8)$ & $-3.2( \pm 1.1)$ & $-2.5( \pm 0.7)$ & $-2.7( \pm 0.7)$ \\
\hline 27 June to 7 July $1998^{c}$ & $\mathrm{CFA}+\mathrm{RBA}$ & -38 & $-5.6( \pm 1.1)$ & $-11.3 \pm 2.2)$ & $-9.8( \pm 2.2)$ & $-11.2 \pm 2.6)$ & $-7.9( \pm 1.6)$ \\
\hline 27 June to 7 July $1998^{c}$ & $\mathrm{OSA}+\mathrm{CTZ}$ & -22 & $-3.4( \pm 0.8)$ & $-6.9( \pm 1.5)$ & $-5.9( \pm 1.5)$ & $-6.7( \pm 1.7)$ & $-4.8( \pm 1.1)$ \\
\hline $11-21$ August $1998^{c}$ & $\mathrm{CFA}+\mathrm{RBA}$ & -11 & $-1.8( \pm 0.6)$ & $-3.6( \pm 1.1)$ & $-3.2( \pm 1.2)$ & $-3.9( \pm 1.3)$ & $-2.6( \pm 0.8)$ \\
\hline $11-21$ August $1998^{\mathrm{c}}$ & $\mathrm{OSA}+\mathrm{CTZ}$ & -19 & $-3.1( \pm 0.8)$ & $-6.1( \pm 1.5)$ & $-5.5( \pm 1.5)$ & $-6.6( \pm 1.8)$ & $-4.4( \pm 1.1)$ \\
\hline $4-11$ September $1999^{b}$ & $\mathrm{CFA}+\mathrm{RBA}$ & -17 & $-0.4( \pm 0.1)$ & $-0.9( \pm 0.2)$ & $-1.0( \pm 0.4)$ & $-0.5( \pm 0.1)$ & $-0.7( \pm 0.2)$ \\
\hline 4-11 September $1999^{b}$ & $\mathrm{OSA}+\mathrm{CTZ}$ & -2.0 & $-0.0( \pm 0.1)$ & $-0.1( \pm 0.1)$ & $-0.1( \pm 0.2)$ & $-.00( \pm 0.0)$ & $-0.1( \pm 0.1)$ \\
\hline $14-18$ September $1999^{c}$ & $\mathrm{CFA}+\mathrm{RBA}$ & -16 & $-1.2( \pm 0.4)$ & $-2.6( \pm 0.5)$ & $-2.2( \pm 0.8)$ & $-2.0( \pm 0.4)$ & $-1.8( \pm 0.4)$ \\
\hline $14-18$ September $1999^{c}$ & $\mathrm{OSA}+\mathrm{CTZ}$ & -7 & $-0.5( \pm 0.2)$ & $-1.0( \pm 0.3)$ & $-0.9( \pm 0.5)$ & $-0.8( \pm 0.2)$ & $-0.7( \pm 0.3)$ \\
\hline Upwelling season & $\mathrm{CFA}+\mathrm{RBA}$ & -23 & $-2.3( \pm 0.6)$ & $-4.7( \pm 1.0)$ & $-4.0( \pm 1.1)$ & $-3.9( \pm 1.0)$ & $-3.2( \pm 0.7)$ \\
\hline Upwelling season & $\mathrm{OSA}+\mathrm{CTZ}$ & -13 & $-1.8( \pm 0.5)$ & $-3.4( \pm 0.8)$ & $-2.9( \pm 0.9)$ & $-3.0( \pm 0.8)$ & $-2.4( \pm 0.6)$ \\
\hline Upwelling season & OSA & -12 & $-1.4( \pm 0.4)$ & $-2.9( \pm 0.7)$ & $-2.4( \pm 0.8)$ & $-2.4( \pm 0.7)$ & $-1.9( \pm 0.5)$ \\
\hline Downwelling season & $\mathrm{CFA}+\mathrm{RBA}$ & -28 & $-4.8( \pm 1.0)$ & $-9.3( \pm 1.9)$ & $-8.2( \pm 1.9)$ & $-9.8( \pm 2.4)$ & $-6.6( \pm 1.5)$ \\
\hline Downwelling season & OSA & -21 & $-3.5( \pm 0.8)$ & $-6.8( \pm 1.5)$ & $-6.0( \pm 1.5)$ & $-7.2( \pm 1.9)$ & $-4.8( \pm 1.2)$ \\
\hline Annual integration & $\mathrm{CFA}+\mathrm{RBA}$ & -26 & $-3.5( \pm 0.8)$ & $-7.0( \pm 1.5)$ & $-6.1( \pm 1.5)$ & $-6.8( \pm 1.7)$ & $-4.9( \pm 1.1)$ \\
\hline Annual integration & $\mathrm{OSA}+\mathrm{CTZ}$ & -17 & $-2.6( \pm 0.6)$ & $-5.1( \pm 1.2)$ & $-4.4( \pm 1.2)$ & $-5.1( \pm 1.4)$ & $-3.6( \pm 0.9)$ \\
\hline Annual integration & OSA & -16 & $-2.4( \pm 0.6)$ & $-4.9( \pm 1.1)$ & $-4.2( \pm 1.2)$ & $-4.8( \pm 1.3)$ & $-3.4( \pm 0.9)$ \\
\hline
\end{tabular}

${ }^{\mathrm{a}}$ See Table 2 for definition of abbreviations. The data from the January 1999 cruise were not used in the integration because the coverage of the continental shelf was poor and also because this cruise corresponded to relatively atypical wintertime conditions (see section 3.2 ), so that the data from January 1998 are considered to be representative for the downwelling season that lasts 6 months. For details on flux computations, see Table 2.

${ }^{\mathrm{b}}$ This is a period of upwelling relaxation.

${ }^{\mathrm{c}}$ This is a period of active upwelling.

change. Only a very small fraction of the shelf was sampled, and undersaturation of $\mathrm{CO}_{2}$ was observed, although $p \mathrm{CO}_{2}$ values were higher than offshore $\left(\mathrm{pCO}_{2} \sim 350 \mu \mathrm{atm}\right)$.

\subsection{Air-Sea Exchange of $\mathrm{CO}_{2}$}

[18] The flux of $\mathrm{CO}_{2}$ across the air-sea interface $(F)$ is computed from the air-sea gradient of $p \mathrm{CO}_{2}\left(\Delta p \mathrm{CO}_{2}=p \mathrm{CO}_{2}\right.$ water $-p \mathrm{CO}_{2}$ atmosphere) and the gas exchange coefficient $K$ using the equation: $F=\alpha K \Delta p \mathrm{CO}_{2}$, where $\alpha$ is the solubility coefficient of $\mathrm{CO}_{2}$. The value of $K$ is mainly controlled by wind speed, and we used three commonly used algorithms [Liss and Merlivat, 1986; Tans et al., 1990; Wanninkhof, 1992] and two recently proposed ones [Wanninkhof and McGillis, 1999; Nightingale et al., 2000]. We decided to use the five parameterizations of the $K$-wind relationship because there is no consensus on the relationships proposed in literature, even in light of recent at-sea experiments with the most up-to-date tracer techniques [Wanninkhof and McGillis, 1999; Nightingale et al., 2000], and also to allow the comparison with $\mathrm{CO}_{2}$ air-sea fluxes reported in literature that are usually computed using only one of the above mentioned relationships.

[19] The CFA is either a small sink or a small source of $\mathrm{CO}_{2}$, and only during upwelling relaxation events (June 1997 and first leg of September 1999, Table 2), the influx of $\mathrm{CO}_{2}$ is comparable to the one in the RBA. Whatever the cruise, the RBA is a strong sink of $\mathrm{CO}_{2}$, in agreement with the strong negative $\Delta p \mathrm{CO}_{2}$ values. The $\mathrm{CO}_{2}$ air-sea fluxes and $\Delta p \mathrm{CO}_{2}$ values in the CTZ are either comparable to those in the RBA as in September 1999 or significantly stronger (August 1998) or significantly weaker (June 1998), but whatever the cruise, they are significantly stronger than in the offshore area (OSA). During the first leg of the September 1999 cruise the OSA was neutral from the point of view of exchange of $\mathrm{CO}_{2}$ with the atmosphere, in accordance with the small $\Delta p \mathrm{CO}_{2}$ and low wind speeds values intrinsically related to an upwelling relaxation event.

[20] The $\mathrm{CO}_{2}$ air-sea fluxes were integrated for each cruise in the continental shelf waters (CFA plus RBA) and in the off-shelf waters (OSA plus CTZ) (Table 3). The air-sea fluxes of $\mathrm{CO}_{2}$ are significantly stronger over the continental shelf waters than in the off-shelf waters for the June 1998 and the second leg of the September 1999 cruises. During all the other cruises, the air-sea $\mathrm{CO}_{2}$ fluxes in the two regions are not significantly different. This is due to the important incertitude introduced in the flux computations by the estimated error on wind speed measurements $( \pm 10 \%)$ that on average, accounts for $60 \%$ of the flux error estimates. However, for most cruises, the $\Delta p \mathrm{CO}_{2}$ values are significantly stronger over the continental shelf than in the off-shelf waters. The exception is the August 1998 cruise when the $\Delta p \mathrm{CO}_{2}$ value was significantly lower in off-shelf waters. This can be attributed to the important extension of the CTZ (see Figure 1) that showed lower $\Delta p \mathrm{CO}_{2}$ values than both the RBA and the CFA (Table 2). This illustrates the significant impact of upwelling filaments on the airsea fluxes of $\mathrm{CO}_{2}$ dynamics in upwelling systems.

[21] The air-sea fluxes of $\mathrm{CO}_{2}$ were integrated for the upwelling season (Table 3 ). The different cruises were separated into active upwelling and upwelling relaxation events according to the discussion in section 3.1 on upwelling index, northerly wind speed component, temperature, and $p \mathrm{CO}_{2}$ fields. We assumed an equal duration for active upwelling and upwelling relaxation events during the upwelling season. Both the continental shelf and the off-shelf waters are significant net sinks of atmospheric $\mathrm{CO}_{2}$ during the upwelling season (Table 3 ).

[22] It is well established that the seasonal variability in the Galician upwelling system is mainly bimodal (upwelling/downwelling seasons), so it is reasonable to attempt an annual integration of the $\mathrm{CO}_{2}$ air-sea fluxes on the basis of data obtained only during summer and winter. The summer data were obtained in three different years, but it is not possible to evaluate the interannual variability from the present data set. Indeed, the differences observed between years can be interpreted in terms of upwelling intensity (intense/low and active upwelling/upwelling relaxation events). The air-sea $\mathrm{CO}_{2}$ fluxes were integrated annually for the continental shelf and the off-shelf waters on the basis of the wellestablished fact that the upwelling and downwelling seasons last 6 months per year each. On an annual basis the net air-sea fluxes of $\mathrm{CO}_{2}$ over the continental shelf range between $-3.5( \pm 0.8)$ and $-7.0( \pm 1.5) \mathrm{mmol} \mathrm{C} \mathrm{m}{ }^{-2} \mathrm{~d}^{-1}$ but are not significantly different 
from the fluxes in off-shelf waters that range between $-2.6( \pm 1.4)$ and $-5.1( \pm 1.2) \mathrm{mmol} \mathrm{C} \mathrm{m}^{-2} \mathrm{~d}^{-1}$.

[23] In an upwelling system, it is reasonable to assume that the air-sea exchange of $\mathrm{CO}_{2}$ is controlled by the input of dissolved inorganic carbon and by the export and/or storage of organic carbon, corresponding to the net ecosystem production (NEP), calculated from gross primary production minus autotrophic and heterotrophic respiration. This computation relies on the determination of various processes that are difficult to assess experimentally and that so far remain unpublished for the study area. So it is easier to compute new primary production that is considered to be equivalent to the production that is exportable from a given ecosystem [e.g., Eppley and Peterson, 1979] from published values of the annual mean of net primary production and of the $f$ ratio. The $f$ ratio is the proportion of primary production that is supported by nitrate and that can be estimated from the relative rates of nitrate and ammonium assimilation [Dugdale and Goering, 1967]. Although a discrepancy between NEP and new primary production has been described in various ecosystems [e.g., Thomas et al., 1999 and references therein], we can assume on a first approximation that the net DIC fixation by phytoplankton corresponds to the new primary production. Joint et al. [2001] report $f$ ratio values over the Galician continental shelf of $0.6( \pm 0.1)$, and Álvarez-Salgado et al. [2001] estimated an annual mean of net primary production of $50( \pm 10) \mathrm{mmol} \mathrm{C} \mathrm{m} \mathrm{m}^{-2} \mathrm{~d}^{-1}$ on the basis of the data from Bode et al. [1996]. Thus the new primary production can be estimated to $30( \pm 11) \mathrm{mmol} \mathrm{C} \mathrm{m} \mathrm{C}^{-2} \mathrm{~d}^{-1}$ off the Galician upwelling system. It is clear that the incertitude on this new primary production estimate is one order of magnitude higher than the airsea $\mathrm{CO}_{2}$ fluxes computed from the $\Delta p \mathrm{CO}_{2}$ field measurements. Furthermore, from the incertitude on the water fluxes reported in the area [Huthnance et al., 2002] we computed a similar incertitude on the input term of $\mathrm{CO}_{2}$ from upwelling. We can conclude that the direct method based on field measurements of $\Delta p \mathrm{CO}_{2}$ (given a sufficiently good spatial and temporal resolution) remains the most efficient method to determine if a given ecosystem is a net source or sink for atmospheric $\mathrm{CO}_{2}$ and to quantify it. Last, the indirect budgeting approach does not account for thermodynamic effects, like temperature variations that can be important as discussed in section 3.1.4.

\subsection{Global Significance?}

[24] Finally, one might inquire about the significance in the global carbon cycle of air-sea $\mathrm{CO}_{2}$ exchange in coastal upwelling areas. So far, annually integrated air-sea fluxes in an upwelling system have only been reported by Goyet et al. [1998] off the Omani coast, which behaves as a net $\mathrm{CO}_{2}$ source of $+2.5( \pm 0.1)$ mmol C m${ }^{-2} \mathrm{~d}^{-1}$, calculated using the Wanninkhof [1992] $K$-wind relationship (we estimated the incertitude on the flux from the precision on $\Delta p \mathrm{CO}_{2}$ of $\pm 2 \mu \mathrm{atm}$ given by Goyet et al. [1998]). The total surface area of coastal upwelling areas is $\sim 3.6 \times 10^{6} \mathrm{~km}^{2}$ [Schlesinger, 1997], so the extrapolation of the Goyet et al. [1998] data would give a net efflux of $+0.039( \pm 0.002) \mathrm{Gt} \mathrm{C} \mathrm{yr}^{-1}$, while the extrapolation of the fluxes we computed off the Galician coast with the same $K$-wind relationship $\left(6.1( \pm 1.5) \mathrm{mmol} \mathrm{C} \mathrm{m}^{-2} \mathrm{~d}^{-1}\right)$ would give an influx of $-0.10( \pm 0.02) \mathrm{Gt} \mathrm{yr}^{-1}$. Although these fluxes are insignificant compared to those in open oceanic waters (1.5 $\left.( \pm 0.8) \mathrm{Gt} \mathrm{C} \mathrm{yr}^{-1}\right)$, they could have an impact on the so-called continental shelf pump introduced by Tsunogai et al. [1999], who computed a net air-sea flux of $-8.0( \pm 0.7) \mathrm{mmol} \mathrm{C} \mathrm{m}{ }^{-2} \mathrm{~d}^{-1}$ that, extrapolated to the worldwide continental shelf area $\left(27 \times 10^{6}\right.$ $\mathrm{km}^{2}$ ), gives a net influx of $-1.0( \pm 0.1) \mathrm{Gt} \mathrm{C} \mathrm{yr}^{-1}$ (we estimated the incertitude on the flux from the precision on $\Delta p \mathrm{CO}_{2}$ of $\pm 5 \mu \mathrm{atm}$ given by Tsunogai et al. [1999]). If we assume that the air-sea $\mathrm{CO}_{2}$ fluxes off the Omani coast are representative of the whole of coastal upwelling areas, this would imply a reduction of $17 \%$
$( \pm 8 \%)$ of the continental shelf pump $\left(-0.780( \pm 0.1) \mathrm{Gt} \mathrm{C} \mathrm{yr}^{-1}\right)$. If the air-sea fluxes we computed are considered representative of the whole of coastal upwelling areas, this would then imply a reduction of only $4 \%( \pm 3 \%)$ of the continental shelf pump $(-0.92$ $\left.( \pm 0.03) \mathrm{Gt} \mathrm{C} \mathrm{yr}{ }^{-1}\right)$. Although neither our computations nor those of Goyet et al. [1998] can be regarded as representative of the $\mathrm{CO}_{2}$ air-sea fluxes for the entirety of coastal upwelling areas, considering the wide range of reported $p \mathrm{CO}_{2}$ values (see section 1), they highlight the potential importance of coastal upwelling systems in verifying and evaluating the continental shelf pump.

\section{Conclusions}

[25] In the present study, we report and discuss surface $p \mathrm{CO}_{2}$ data obtained off the Galician coast characterized by seasonal upwelling. The $p \mathrm{CO}_{2}$ values over the continental shelf range between 265 and $415 \mu \mathrm{atm}$ during summer (upwelling season) and between 316 and $345 \mu \mathrm{atm}$ during winter (downwelling season). In spite of the important spatial heterogeneity and temporal variability related to the oscillation between active upwelling and upwelling relaxation events, both continental shelf areas and off-shelf waters are net sinks of $\mathrm{CO}_{2}$ during the upwelling season. The computed air-sea fluxes of $\mathrm{CO}_{2}$ over the continental shelf yield a net influx in the range of $-2.3( \pm 0.6)$ to $-4.7( \pm 1.0) \mathrm{mmol} \mathrm{C} \mathrm{m}^{-2}$ $\mathrm{d}^{-1}$ during the upwelling season and $-3.5( \pm 0.8)$ to $-7.0( \pm 1.5)$ mmol $\mathrm{C} \mathrm{m}^{-2} \mathrm{~d}^{-1}$ on an annual basis for the Liss and Merlivat [1986] and the Tans et al. [1990] formulations of the $\mathrm{CO}_{2}$ exchange coefficient, respectively. Although the air-sea gradient of $\mathrm{CO}_{2}$ is significantly stronger over the continental shelf waters, the computed fluxes are not significantly different from those computed for the off-shelf waters that range from $-1.8( \pm 0.5)$ to $-3.42( \pm 0.8) \mathrm{mmol} \mathrm{C} \mathrm{m} \mathrm{C}^{-2} \mathrm{~d}^{-1}$ during the upwelling season and from $-2.6( \pm 0.6)$ to $-5.1( \pm 1.2) \mathrm{mmol} \mathrm{C} \mathrm{m}^{-2} \mathrm{~d}^{-1}$ on an annual basis, again depending on the choice of the formulation of the $K$ wind relationship. As expected, the relatively large incertitude on the flux estimates comes mainly from the estimated error on wind speed measurements. During the downwelling season the distribution of $p \mathrm{CO}_{2}$ is mainly related to the cooling of seawater and the presence of different water masses related to the slope poleward current and the input of fresh water from the rías.

[26] It is reasonable to assume that during the upwelling season the $\Delta p \mathrm{CO}_{2}$ field and related $\mathrm{CO}_{2}$ air-sea exchange are imposed by the balance between the input of $\mathrm{CO}_{2}$-rich deep upwelled water and the output of organic carbon to both the sediment and across the continental shelf break (i.e., new primary production). However, the large incertitude on the new primary production and water fluxes estimates makes it unlikely to verify this hypothesis through an indirect budgeting approach.

[27] The impact of coastal upwelling areas on the continental shelf pump was briefly envisaged and allows us to conclude that more field data of the distribution of surface water $p \mathrm{CO}_{2}$ are needed over continental shelf areas worldwide. Furthermore, we observed rapid changes in the distribution of $p \mathrm{CO}_{2}$ at a weekly timescale that stress the need of carefully thought out sampling strategies in dynamic coastal waters to minimize problems of data integration related to synopticity.

[28] Acknowledgments. The authors would like to thank officers and crew of the RV Belgica, RRS Charles Darwin, and RV Meteor for welcome on board; MUMM (Belgium), RVS (UK), and BSH (Germany) for thermosalinograph and meteorological data; NOAA PFEL for upwelling index data; Peter Miller (PML, UK) for processing the latter; Tim Smyth (PML, UK) for obtaining ECMWF data; Claire Daemers, Renzo Biondo, and Emile Libert (ULg, Belgium) for technical assistance; Jake Loncar and Alison Fairclough (BODC, UK) for data management; numerous colleagues for fruitful discussions; and two anonymous reviewers for pertinent comments that greatly improved the quality of a previous version of the 
manuscript. This work was funded by the European Commission (OMEX II project, Marine Science and Technology programme, contract MAS3CT97-0076). Alberto Vieira Borges received financial support from the Fonds pour la Formation à la Recherche dans l'Industrie et l'Agriculture (Belgium) and the European Commission (EUROTROPH project, EVK3CT-2000-00040). Michel Frankignoulle is a research associate at the Fonds National de la Recherche Scientifique (Belgium). This is Eloise contribution 252 .

\section{References}

Alongi, D. M. (Ed.), Coastal Ecosystem Processes, 419 pp., CRC Press, Boca Raton, Fla., 1998

Álvarez-Salgado, X. A., G. Rosón, F. F. Pérez, and Y. Pazos, Hydrographic variability off the Rías Baixas (NW Spain) during the upwelling season, J. Geophys. Res., 98, 14,445-14,447, 1993.

Álvarez-Salgado, X. A., C. G. Castro, F. F. Pérez, and F. Fraga, Nutrient mineralization patterns in shelf waters of the western Iberian upwelling, Cont. Shelf Res., 17, 1247-1270, 1997.

Álvarez-Salgado, X. A., M. D. Doval, and F. F. Pérez, Dissolved organic matter in shelf waters off the Ría de Vigo (NW Iberian upwelling system), J. Mar. Syst., 18, 383-394, 1999.

Álvarez-Salgado, X. A., M. D. Doval, A. V. Borges, I. Joint, M. Frankignoulle, E. M. S. Woodward, and F. G. Figueiras, Off-shelf fluxes of labile materials by an upwelling filament in the NW Iberian upwelling system, Progr. Oceanogr., 51, 321-337, 2001.

Arar, E. J., Determination of chlorophyll $a$ and $b$ and identification of other pigments of interest in marine and freshwater algae using high performance liquid chromatography with visible wavelength detection, in Methods for the Determination of Chemical Substances in Marine and Estuarine Environmental Matrices, 447, pp. 1-20, U.S. Environ. Protection Agency, Cincinnati, Ohio, 1997.

Bakker, D. C. E., H. J. W. de Barr, and H. P. J. de Wilde, Dissolved carbon dioxide in Dutch coastal waters, Mar. Chem., 55, 247-263, 1996.

Bakker, D. C. E., H. J. W. de Baar, and E. de Jong, The dependence on temperature and salinity of dissolved inorganic carbon in the east Atlantic surface waters, Mar. Chem., 65, 263-280, 1999.

Benson, B. B., and D. Krause, The concentration and isotopic fractionation of oxygen dissolved in freshwater and seawater in equilibrium with the atmosphere, Limnol. Oceanogr., 29, 620-632, 1984.

Bode, A., B. Casas, E. Fernández, E. MaraZon, P. Serret, and M. Varela, Phytoplankton biomass and production in shelf waters off NW Spain: Spatial and seasonal variability in relation to upwelling, Hydrobiologia, 341, 225-234, 1996.

Borges, A. V., and M. Frankignoulle, Daily and seasonal variations of the partial pressure of $\mathrm{CO}_{2}$ in surface seawater along the Belgian and southern Dutch coastal areas, J. Mar. Syst., 19, 251-266, 1999.

Borges, A. V., and M. Frankignoulle, Short-term variations of the partial pressure of $\mathrm{CO}_{2}$ in surface waters of the Galician upwelling system, Progr. Oceanogr., 51, 283-302, 2001.

Borges, A. V., and M. Frankignoulle, Aspects of dissolved inorganic carbon dynamics in the upwelling system off the Galician coast, J. Mar. Syst., 32, $181-198,2002$.

Brasse, S., A. Reimer, R. Seifert, and W. Michaelis, The influence of intertidal mudflats on the dissolved inorganic carbon and total alkalinity in the German Bight, southeastern North Sea, J. Sea Res., 42, 93-103, 1999.

Cai, W.-J., L. R. Pomeroy, M. A. Moran, and Y. Wang, Oxygen and carbon dioxide mass balance for estuarine-intertidal marsh complex of five rivers in the southeastern U. S., Limnol. Oceanogr., 44, 639-649, 1999.

Copin-Montégut, C., A new formula for the effect of temperature on the partial pressure of carbon dioxide in seawater, Mar. Chem., 25, 29-37, 1988.

Copin-Montégut, C., and B. Avril, Continuous measurements in surface water of the northeastern tropical Atlantic, Tellus, Ser. B, 47, 86-92, 1995.

Copin-Montégut, C., and P. Raimbault, The Peruvian upwelling near $15^{\circ} \mathrm{S}$ in August 1986: Results of continuous measurements of physical and chemical properties between 0 and $200 \mathrm{~m}$ depth, Deep Sea Res., Part $I, 41,439-467,1994$.

Culkin, F., The major constituents of seawater, in Chemical Oceanography, vol. 2, edited by J. P Riley and G. Skirrow, pp. 121-161, Academic, San Diego, Calif., 1965.

Dickson, A. G., Thermodynamics of the dissociation of boric acid in synthetic sea water from 273.15 to 298.15 K, Deep Sea Res., 37, 755-766, 1990.

Dickson, A. G., pH buffers for seawater media based on the total hydrogen ion concentration scale, Deep Sea Res., 40, 107-118, 1993.
Department of Energy, Handbook of Methods for the Analysis of the Various Parameters of the Carbon Dioxide System in Sea Water, edited by A. G. Dickson and C. Goyet, ORNL/CDIAC-74, Washington, D. C., 1994. Doval, M. D., X. A. Álvarez-Salgado, and F. F. Pérez, Dissolved organic matter in a temperate embayment affected by coastal upwelling, Mar. Ecol. Prog. Ser., 157, 21-37, 1997.

Dugdale, R. C., and J. J. Goering, Uptake of new and regenerated forms of nitrogen in primary production, Limnol. Oceanogr., 12, 196-206, 1967.

Eppley, R. W., and B. J. Peterson, Particulate organic matter flux and planktonic new production in the deep oceans, Nature, 282, 677-680, 1979.

Figueiras, F. G., X. A. Álvarez-Salgado, L. M. Lorenzo, G. H. Tilstone, and M. D. Doval, Chemical and biological study of the NW Iberian margin: Short-time and seasonal scale changes of mesoscale structures, in Final Science Report, Ocean Margin Exchange OMEX II, Phase II, contract MAS3-CT97-0076, vol. 2, pp. 419-443, Eur. Comm., Brussels, 2001.

Fraga, F., Upwelling off the Galician coast, northwest Spain, in Coastal Upwelling, Coastal and Estuarine Sci., vol.1, edited by F. A. Richards, pp. 176-182, AGU, Washington, D. C., 1981.

Fraga, F., F. F. Pérez, F. G. Figueiras, and A. F. Ríos, Stoichiometric variations of $\mathrm{N}, \mathrm{P}, \mathrm{C}$ and $\mathrm{O}_{2}$ during a Gymnodinium catenatum red tide and their interpretation, Mar. Ecol. Prog. Ser., 87, 123-134, 1992.

Frankignoulle, M., and A. V. Borges, European continental shelf as a significant sink for atmospheric carbon dioxide, Global Biogeochem. Cycles, 15, 569-576, 2001.

Frankignoulle, M., G. Avril, A. Borges, I. Bourge, C. Canon, B. Delille, E. Libert, and J.-M. Théate, Carbon dioxide emission from European estuaries, Science, 282, 434-436, 1998.

Frankignoulle, M., A. Borges, and R. Biondo, A new design of equilibrator to monitor carbon dioxide in highly dynamic and turbid environments, Water Res., 35, 1344-1347, 2001.

Frouin, R., A. F. G. Fiúza, I. Ambar, and T. J. Boyd, Observations of a poleward surface current off the coasts of Portugal and Spain during winter, J. Geophys. Res., 95, 679-691, 1990.

Gattuso, J.-P., M. Frankignoulle, and R. Wollast, Carbon and carbonate metabolism in coastal aquatic ecosystems, Annu. Rev. Ecol. Syst., 29, 405-433, 1998.

Goyet, C., F. J. Millero, D. W. O'Sullivan, G. Eischeid, S. J. McCue, and R. G. J. Bellerby, Temporal variations of $p \mathrm{CO}_{2}$ in surface seawater of the Arabian Sea in 1995, Deep Sea Res., Part I, 45, 609-623, 1998.

Haynes, R., and E. D. Barton, A poleward flow along the Atlantic coast of the Iberian Peninsula, J. Geophys. Res., 95, 11,425-11,441, 1990.

Haynes, R., and E. D. Barton, Lagrangian observations in the Iberian Coastal Transition Zone, J. Geophys. Res., 95, 14,731-14,741, 1991.

Haynes, R., E. D. Barton, and I. Pilling, Development, persistence, and variability of upwelling filaments off the Atlantic coast of the Iberian Peninsula, J. Geophys. Res., 98, 22,681-22,692, 1993.

Hoppema, J. M. J., The seasonal behaviour of carbon dioxide and oxygen in the coastal North Sea along the Netherlands, Neth. J. Sea Res., 28, $167-179,1991$

Huthnance, J. M., H. M. van Aken, M. White, E. D. Barton, B. L. Le Cann, E. M. Coelho, E. A. Fanjul, P. Miller, and J. Vitorino, Ocean margin exchanges-Water Flux Estimates, J. Mar. Syst., 32, 107-137, 2002.

Joint, I., A. Rees, and M. Woodward, Primary production and nutrient assimilation in the Iberian upwelling in August 1998, Progr. Oceanogr., $51,303-329,2001$

Keeling, C. D., and T. P. Whorf, Atmospheric $\mathrm{CO}_{2}$ records from sites in the SIO air sampling network, in Trends: A Compendium of Data on Global Change, Carbon Dioxide Inf. Anal. Center, Oak Ridge, Tenn., 1999.

Kelley, J. J., and D. W. Hood, Carbon dioxide in the Pacific Ocean and Bearing Sea: Upwelling and mixing, J. Geophys. Res., 76, 745-753, 1971.

Körtzinger, A., J. C. Duinker, and L. Mintrop, Strong $\mathrm{CO}_{2}$ emissions from the Arabian Sea during south-west monsoon, Geophys. Res. Lett., 24, 1763-1766, 1997.

Lefèvre, N., G. Moore, J. Aiken, A. Watson, D. Cooper, and R. Ling, Variability of $p \mathrm{CO}_{2}$ in the tropical Atlantic in 1995, J. Geophys. Res., 103, 5623-5634, 1998.

Liss, P., and L. Merlivat, Air-sea exchange rates: Introduction and synthesis, in The role of Air-Sea Exchanges in Geochemical Cycling, NATO ASI Ser., Ser. C, vol. 185, edited P. Buat-Ménard, pp. 113-118, D. Reidel, Norwell, Mass., 1986.

Mantoura, R. F. C., S. G. Gibb, D. Cummings, C. A. Llewellyn, and R. Barlow, Pigment chemotaxonomy of phytoplankton at the NW Iberian shelf and margin, in Final Science Report, Ocean Margin Exchange OMEX II, Phase II, contract MAS3-CT97-0076, vol. 1, pp. 117-124, Eur. Comm., Brussels, 2001.

McClain, C. R., S.-Y. Chao, L. P. Atkinson, J. O. Blanton, and F. de 
Catillejo, Wind-driven upwelling in the vicinity of Cape Finisterre, Spain, J. Geophys. Res., 91, 8470-8486, 1986.

Miller, P., S. Groom, T. Smyth, and K. Woods, Remote sensing in OMEX II-II, in Final Science Report, Ocean Margin Exchange OMEX II, Phase II, contract MAS3-CT97-0076, vol. 1, pp. 173-190, Eur. Comm., Brussels, 2001.

Nightingale, P. D., G. Malin, C. S. Law, A. J. Watson, P. S. Liss, M. I. Liddicoat, J. Boutin, and R. C. Upstill-Goddard, In situ evaluation of airsea exchange parameterizations using novel conservative and volatile tracers, Global Biogeochem. Cycles, 14, 373-387, 2000.

Nogueira, E., F. F. Pérez, and A. F. Ríos, Modelling thermohaline properties in an estuarine upwelling ecosystem (Ría of Vigo: NW Spain) using BoxJenkins transfer function models, Estuarine Coastal Shelf Sci., 44, 685$702,1997$.

Nogueira, E., F. F. Pérez, and A. F. Ríos, Modelling nutrients and chlorophyll $a$ time series in an estuarine upwelling ecosystem (Ría of Vigo: NW Spain) using the Box-Jenkins approach, Estuarine Coastal Shelf Sci., 46, 267-286, 1998 .

Pérez, F. F., A. F. Ríos, and G. Rosón, Sea surface carbon dioxide off the Iberian Peninsula (north eastern Atlantic Ocean), J. Mar. Syst., 19, 27 46, 1999.

Pingree, R. D., and B. Le Cann, Structure, strength and seasonality of the slope currents in the Bay of Biscay region, J. Mar. Biol. Assoc. UK, 70, $857-885,1990$

Roy, R. N., L. N. Roy, K. M. Vogel, C. Porter-Moore, T. Pearson, C. E. Good, F. J. Millero, and D. J. Cambell, Determination of the ionization constants of carbonic acid in seawater in salinities 5 to 45 and temperatures 0 to $45^{\circ} \mathrm{C}$, Mar. Chem., 44, 249-267, 1993.

Sabine, C. L., R. Wanninkhof, R. M. Key, C. Goyet, and F. J. Millero, Seasonal fluxes in the tropical and subtropical Indian Ocean, Mar. Chem., $72,33-53,2000$.

Schlesinger, W. H. (Ed.), Biogeochemistry: An Analysis of Global Change, 588 pp., Academic, San Diego, Calif., 1997.

Schwing, F. B., M. O'Farrel, J. Steger, and K. Baltz, Coastal upwelling indices, West Coast of North America 1946-1995, Tech. Memo. NMFS SWFSC-231, Natl. Oceanic and Atmos. Admin., Silver Spring, Md., 1996.

Simpson, J. J., On the exchange of oxygen and carbon dioxide between ocean and atmosphere in an eastern boundary current, in Gas Transfer at Water Surfaces, edited by W. Brutsaert and G. H. Jirka, pp. 505-514, D. Reidel, Norwell, Mass., 1984.

Simpson, J. J., and A. Zirino, Biological control of $\mathrm{pH}$ in the Peruvian coastal upwelling area, Deep Sea Res., 27, 234-248, 1980.

Smith, S. V., and F. T. Mackenzie, The ocean as a net heterotrophic system: Implications from the carbon biogeochemical cycle, Global Biogeochem. Cycles, 1, 187-198, 1987.

Smith, S. V., and J. T. Hollibaugh, Coastal metabolism and the oceanic organic carbon balance, Rev. Geophys., 31, 75-89, 1993.

Stevens, I., M. Hamann, J. A. Johnson, and A. F. G. Fiuza, Comparisons between a fine resolution model and observations in the Iberian shelfslope region, J. Mar. Syst., 26, 53-74, 2000.
Takahashi, T., R. A. Feely, R. F. Weiss, R. H. Wanninkhof, D. W. Chipman, S. C. Sutherland, and T. T. Takahashi, Global air-sea flux of $\mathrm{CO}_{2}$ : An estimate based on measurements of sea-air $p \mathrm{CO}_{2}$ difference, Proc. Natl. Acad. Sci. USA, 94, 8292-8299, 1997.

Takahashi, T., R. H. Wanninkhof, R. A. Feely, R. F. Weiss, D. W. Chipman, N. Bates, J. Olafsson, C. Sabine, and S. C. Sutherland, Net air-sea $\mathrm{CO}_{2}$ flux over the global ocean: An improved estimate based on the sea-air $p \mathrm{CO}_{2}$ difference, paper presented at 2nd International Symposium on $\mathrm{CO}_{2}$ in the Oceans, Cent. for Global Environ. Res., Tsukuba, Japan, Jan. 1999

Tans, P. P., I. Y. Fung, and T. Takahashi, Observational constraints on the global atmospheric $\mathrm{CO}_{2}$ budget, Science, 247, 1431-1438, 1990.

Thomas, H., and B. Schneider, The seasonal cycle of carbon dioxide in Baltic Sea surface waters, J. Mar. Syst, 22, 53-67, 1999.

Thomas, H., V. Ittekkot, C. Osterrohtand, and B. Schneider, Preferential recycling of nutrients-The ocean's way to increase new primary production and to pass nutrient limitation?, Limnol. Oceanogr., 44, 1999-2004, 1999.

Tilstone, G. H., F. G. Figueiras, E. G. Fermín, and D. Arbones, Significance of nanoplankton photosynthesis and primary production in a coastal upwelling system (Ría of Vigo, NW Spain), Mar. Ecol. Prog. Ser., 183, $13-$ 27, 1999 .

Torres, R., D. R. Turner, N. Silva, and J. Rutllant, High short-term variability of $\mathrm{CO}_{2}$ fluxes during an upwelling event off the Chilean coast at 30 ${ }^{\circ}$ S, Deep Sea Res., Part I, 46, 1161-1179, 1999.

Tsunogai, S., S. Watanabe, and T. Sato, Is there a "continental shelf pump" for the absorption of atmospheric $\mathrm{CO}_{2}$ ?, Tellus, Ser. B, 51, 701-712, 1999.

Van Green, A., R. K. Takesue, J. Goddard, T. Takahashi, J. A. Barthand, and R. L. Smith, Carbon and nutrient dynamics during coastal upwelling off Cape Blanco, Oregon, Deep Sea Res., Part II, 47, 975-1002, 2000.

Walsh, J. J., On the Nature of Continental Shelves, 520 pp., Academic, San Diego, Calif., 1988.

Wang, S.-L., C.-T. A. Chen, G.-H. Hong, and C.-S. Chung, Carbon dioxide and related parameters in the East China Sea, Cont. Shelf Res., 20, $525-$ $544,2000$.

Wanninkhof, R., Relationship between wind speed and gas exchange over the ocean, J. Geophys. Res., 97, 7373-7382, 1992.

Wanninkhof, R., and W. R. McGillis, A cubic relationship between air-sea $\mathrm{CO}_{2}$ exchange and wind speed, Geophys. Res. Lett., 26, 1889-1892, 1999. Weiss, R. F., Carbon dioxide in water and seawater: The solubility of a nonideal gas, Mar. Chem., 2, 203-215, 1974

Wollast, R., Evaluation and comparison of the global carbon cycle in the coastal zone and in the open ocean, in The Sea, vol. 10, edited by K. H. Brink, and A. R. Robinson, pp. 213-252, John Wiley, New York, 1998.

A. V. Borges and M. Frankignoulle, Unité d'Océanographie Chimique, Institut de Physique B5, Université de Liège, B-4000 Sart Tilman, Belgium. (alberto.borges@ulg.ac.be) 

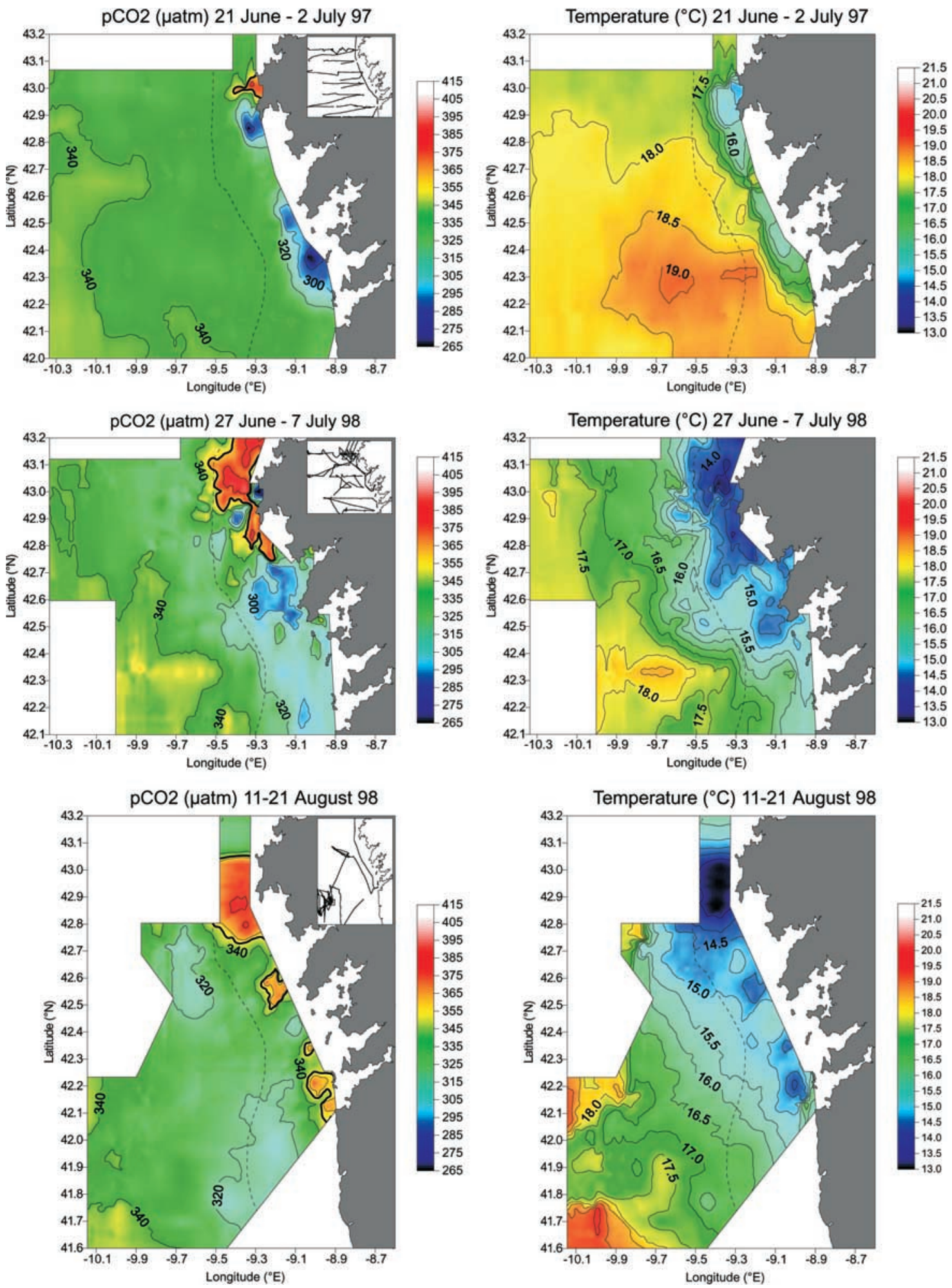

Figure 2. Surface water distributions of $\mathrm{pCO}_{2}$ ( $\mu \mathrm{atm}$ ) and temperature $\left({ }^{\circ} \mathrm{C}\right.$ ) in June 1997, June 1998, and August 1998. The dashed line corresponds to the $200 \mathrm{~m}$ isobath. The thick line corresponds to atmospheric $p \mathrm{CO}_{2}$. 

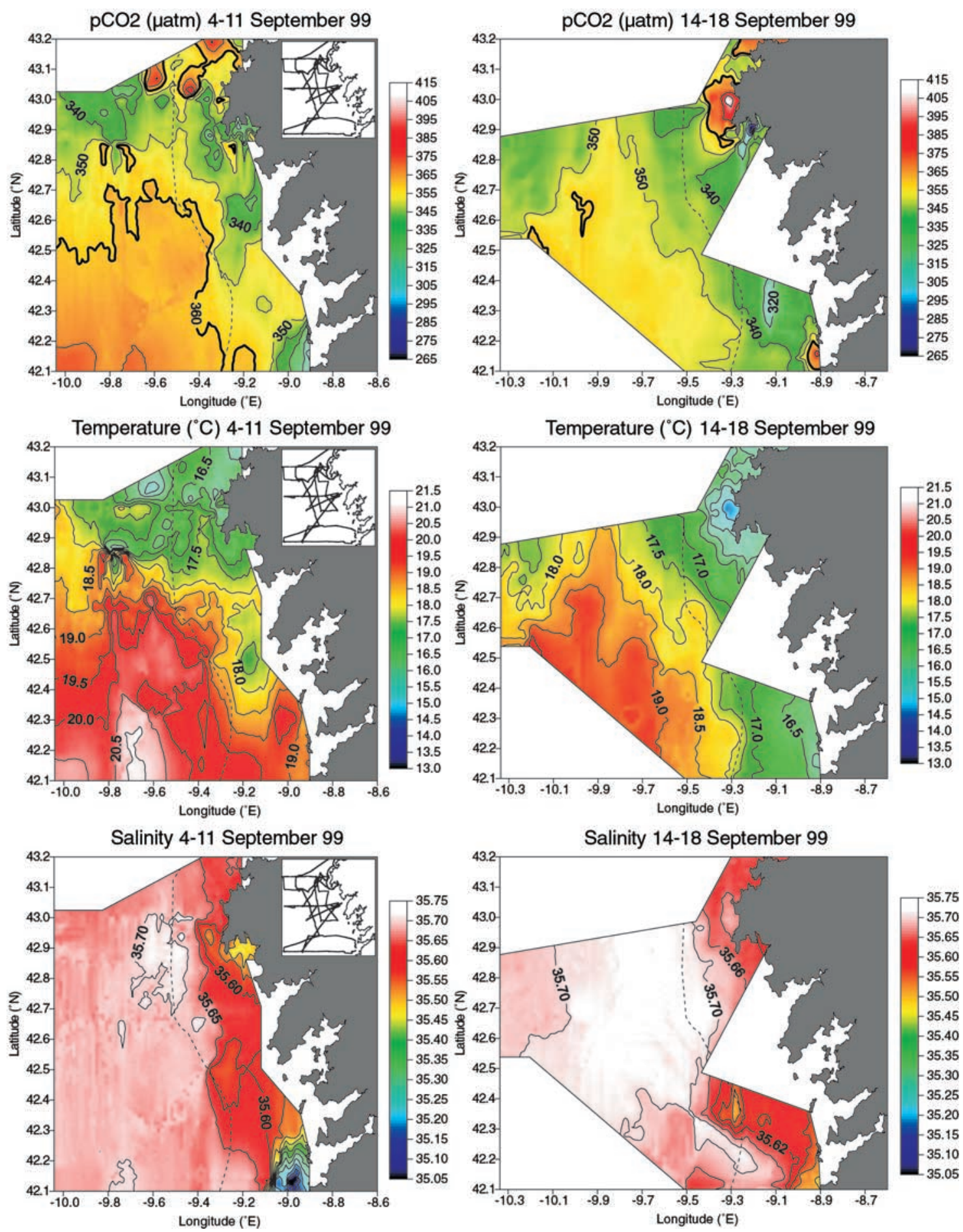

Figure 3. Surface water distributions of $p \mathrm{CO}_{2}(\mu \mathrm{atm})$, temperature $\left({ }^{\circ} \mathrm{C}\right)$, and salinity during the first and second legs of the September 1999 cruise. The dashed line corresponds to the $200 \mathrm{~m}$ isobath. The thick line corresponds to atmospheric $p \mathrm{CO}_{2}$. 

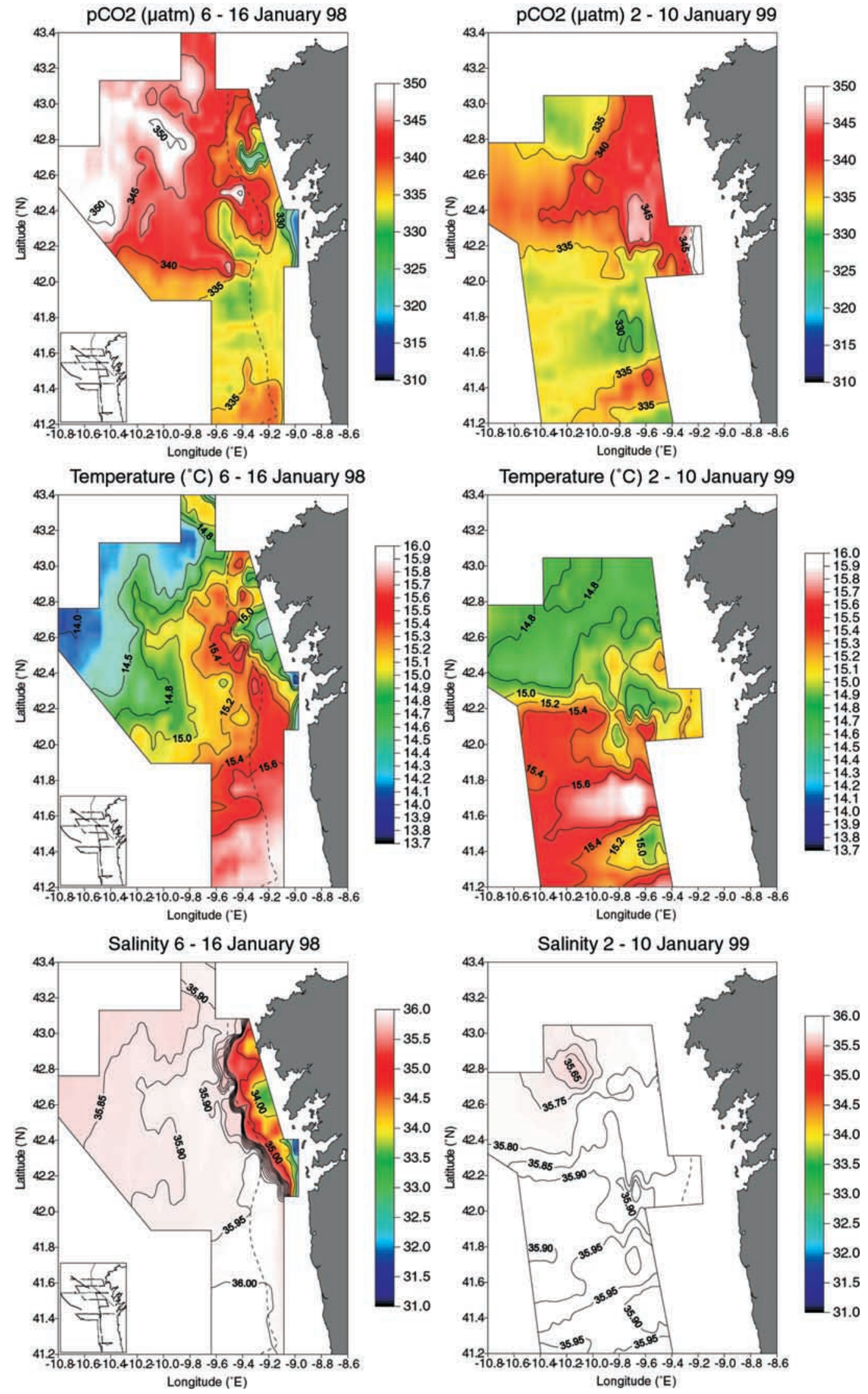

Figure 7. Surface water distributions of $p \mathrm{CO}_{2}$ ( $\left.\mu \mathrm{atm}\right)$, temperature $\left({ }^{\circ} \mathrm{C}\right)$, and salinity in January 1998 and 1999 . The dashed line corresponds to the $200 \mathrm{~m}$ isobath. The thick line corresponds to atmospheric $p \mathrm{CO}_{2}$. 